\title{
Impaired Short-Term Functioning of a Benthic Community from a Deep Norwegian Fjord Following Deposition of Mine Tailings and Sediments
}

\section{OPEN ACCESS}

Edited by:

Ricardo Serrão Santos,

University of the Azores, Portugal

Reviewed by:

Akkur Vasudevan Raman

Andhra University, India

Daniela Zeppilli,

French Research Institute for

Exploitation of the Sea, France

*Correspondence:

Lisa Mevenkamp

lisa.mevenkamp@ugent.be

Tanja Stratmann

tanja.stratmann@nioz.nl

${ }^{\dagger}$ These authors have contributed equally to this work.

Specialty section:

This article was submitted to Deep-Sea Environments and Ecology, a section of the journal Frontiers in Marine Science

Received: 17 March 2017 Accepted: 15 May 2017 Published: 30 May 2017

Citation:

Mevenkamp L, Stratmann T, Guilini K, Moodley L, van Oevelen D,

Vanreusel $A$, Westerlund $S$ and

Sweetman AK (2017) Impaired

Short-Term Functioning of a Benthic Community from a Deep Norwegian Fjord Following Deposition of Mine

Tailings and Sediments.

Front. Mar. Sci. 4:169. doi: 10.3389/fmars.2017.00169

\author{
Lisa Mevenkamp ${ }^{1 * t}$, Tanja Stratmann ${ }^{2 * t}$, Katja Guilini ${ }^{1}$, Leon Moodley ${ }^{3}$, \\ Dick van Oevelen ${ }^{2}$, Ann Vanreusel ${ }^{1}$, Stig Westerlund ${ }^{3}$ and Andrew K. Sweetman ${ }^{4}$ \\ ${ }^{1}$ Marine Biology Research Group, Ghent University, Ghent, Belgium, ${ }^{2}$ NIOZ Royal Netherlands Institute for Sea Research, \\ Department of Estuarine and Delta Systems, Utrecht University, Yerseke, Netherlands, ${ }^{3}$ Environment Department, \\ International Research Institute of Stavanger, Randaberg, Norway, ${ }^{4}$ The Lyell Centre for Earth and Marine Science and \\ Technology, Heriot-Watt University, Edinburgh, United Kingdom
}

The extraction of minerals from land-based mines necessitates the disposal of large amounts of mine tailings. Dumping and storage of tailings into the marine environment, such as fjords, is currently being performed without knowing the potential ecological consequences. This study investigated the effect of short-term exposure to different deposition depths of inert iron ore tailings $(0.1,0.5$, and $3 \mathrm{~cm})$ and dead subsurface sediment $(0.5$ and $3 \mathrm{~cm})$ on a deep water $(200 \mathrm{~m})$ fjord benthic assemblage in a microcosm experiment. Biotic and abiotic variables were measured to determine structural and functional changes of the benthic community following an 11 and 16 day exposure with tailings and dead sediment, respectively. Structural changes of macrofauna, meiofauna, and bacteria were measured in terms of biomass, density, community composition and mortality while measures of oxygen penetration depth, sediment community oxygen consumption and ${ }^{13} \mathrm{C}$-uptake and processing by biota revealed changes in the functioning of the system. Burial with mine tailings and natural sediments modified the structure and functioning of the benthic community albeit in a different way. Mine tailings deposition of $0.1 \mathrm{~cm}$ and more resulted in a reduced capacity of the benthic community to remineralize fresh ${ }^{13} \mathrm{C}$-labeled algal material, as evidenced by the reduced sediment community oxygen consumption and uptake rates in all biological compartments. At $3 \mathrm{~cm}$ of tailings deposition, it was evident that nematode mortality was higher inside the tailings layer, likely caused by reduced food availability. In contrast, dead sediment addition led to an increase in oxygen consumption and bacterial carbon uptake comparable to control conditions, thereby leaving deeper sediment layers anoxic and in turn causing nematode mortality at $3 \mathrm{~cm}$ deposition. This study clearly shows that even small levels $(0.1 \mathrm{~cm})$ of instantaneous burial by mine tailings may significantly reduce benthic ecosystem functioning on the short term. Furthermore, it 
reveals the importance of substrate characteristics and origin when studying the effects of substrate addition on marine benthic fauna. Our findings should alert decision makers when considering approval of new deep-sea tailings placement sites as this technique will have major negative impacts on benthic ecosystem functioning over large areas.

Keywords: submarine tailings placement, anthropogenic disturbance, deep sea, benthos, algal carbon, pulsechase analysis, ${ }^{13} \mathrm{C}$-labeling

\section{INTRODUCTION}

The extraction of mineral resources on land produces large amounts of fine waste material known as mine tailings (Jamieson, 2011). About $60 \%$ (iron) to $99.99 \%$ (gold) of the ore processed in mines is discarded as non-economic by-product resulting in an annual waste production of 14 billion tons of fine tailings worldwide (Jones and Boger, 2012; Vogt, 2013). While many solutions for the recycling of tailings have been proposed (Bian et al., 2012; Adiansyah et al., 2015), the vast majority is discarded in landfills, lakes, riverine systems, and the marine environment. The environmental and socio-economic consequences of tailings disposal can be devastating so that a proper management and sustainable use of mine tailings requires more attention (Franks et al., 2011; Bian et al., 2012; Adiansyah et al., 2015). For reasons of risk reduction on land as well as economic and esthetical considerations (Kvassnes and Iversen, 2013) the disposal of inert tailings material into streams and the marine environment known as riverine tailings disposal (RTD), submarine tailings placement (STP) and deep-sea tailings placement (DSTP) have been proposed and implemented (Vogt, 2013). But, due to the irreversible environmental impacts resulting from direct tailings discharge into riverine systems the use of this approach has seized and RTD is no longer implemented (Vogt, 2013). Submarine tailings placement, however, is allowed and applied at 14 mining sites worldwide (status in 2013) while new sites are still being targeted (Vogt, 2013). Currently, $0.6 \%$ of all industrial-sized mines discharge their tailings into the marine environment with Norway as main contributor (Vogt, 2013). In 2013, Norway, the country with most STP sites worldwide, had 7 operational STP sites, and 2 sites in a planning stage (Kvassnes and Iversen, 2013).

STP occurs mainly at continental margins at depths between 30 and 1,000 m or more including highly productive ecosystems such as fjords and canyons (de Leo et al., 2010; Vogt, 2013; Thurber et al., 2014). Continental margins are significant contributors to biodiversity and productivity and fulfil an important role for the provision of ecosystem services (Walsh, 1991). These include a wide range of regulatory services such as nutrient cycling, natural carbon sequestration and primary and secondary production, but also direct provisioning services such as fisheries and mineral or genetic resources (Armstrong et al., 2012; Thurber et al., 2014). Despite this key role, only few studies have assessed the impacts of mine tailings disposal on the functioning of bathyal benthic communities. The environmental impacts of STP can be manifold, including hyper-sedimentation, changes in grain size, smothering of benthic fauna and toxicity by the release of heavy metals or chemicals (Ramirez-Llodra et al., 2015). To prevent irreversible impacts on the environment it is of particular interest to get an understanding of the risks of STP and the magnitude of its impact on marine biota and ecosystem functioning. A large amount of scientific data is available in the "gray literature" from monitoring programs accompanying STP operations (Ramirez-Llodra et al., 2015). However, many of these monitoring studies only report impacts on one or few aspects of the ecosystem and often good baseline studies are lacking (Ramirez-Llodra et al., 2015). Furthermore, to be able to give recommendations for future environmental management with regard to land-based mining but also regarding possible future marine mining scenarios, it is crucial to investigate threshold values for tailings deposition. And although monitoring studies have incorporated the impact of tailings disposal at various distances from the outfall (Olsgard and Hasle, 1993) it is difficult to infer threshold values for the directly impacted communities as benthic fauna might naturally vary with depth and distance from the outfall due to changes in grain size or food availability. Especially the composition of meiofauna taxa and nematode species in particular and their vertical distribution in the sediment are strongly determined by abiotic factors such as grain size and sediment oxygenation (Jansson, 1967; Higgins and Thiel, 1988; Coull, 1999; Moodley et al., 2000b) making this group particularly vulnerable to sediment burial and disturbance.

Some important ecosystem functions e.g., organic matter remineralization or primary and secondary production are strongly driven by biotic factors such as biomass, diversity, or bioturbation (Lohrer et al., 2004; Danovaro et al., 2008; Braeckman et al., 2010). Moreover, different trophic levels and functional groups can exhibit tight interactions, and changes in the structure of one taxon can have strong repercussions on others which in turn influences ecosystem functioning (Gilbertson et al., 2012; Piot et al., 2013). Therefore, to fully understand the complexity of the processes shaping the structure and functioning of benthic ecosystems under various stressors, well-designed, controlled experiments resembling natural conditions as close as possible, including multiple trophic levels, and community-based approaches, are needed (Hale et al., 2011; Wernberg et al., 2012). Oxygen consumption is a good proxy for the depth-integrated overall remineralization of organic matter by benthic communities through aerobic and anaerobic processes (Moodley et al., 1998; Middelburg et al., 2005; Glud, 2008) and has been proven a very useful indicator in various impact studies (Vanaverbeke et al., 2008; e.g., Sweetman et al., 2010, 2014). Furthermore, the processing of organic matter can be traced through different trophic levels by introducing labile organic material with isotopically enriched carbon signatures (Middelburg et al., 2000; Boschker and Middelburg, 2002; van Oevelen et al., 2006a). In combination with estimates of biomass 
and density it is also possible to assess the relative contribution of each biotic component to the observed functional changes (van Oevelen et al., 2006b).

To understand the potential environmental impacts of DSTP on the structure and functioning of soft-sediment communities and to assess threshold levels for tailings deposition, we conducted a microcosm experiment with soft-bottom fauna from a deep Norwegian fjord. For this purpose, natural, undisturbed sediments were incubated in the laboratory under in-situ conditions and subjected to three different levels of deposition with mine tailings. Structural changes of the macrofaunal, meiofaunal and bacterial communities were assessed using measures of biomass, densities, and diversity. Furthermore, mortality was assessed in macrofauna by "lifechecking" and in meiobenthic nematodes by using a staining technique with Trypan Blue. Next to these structural impacts we investigated ecosystem functioning responses such as oxygen consumption dynamics and phytodetritus processing by the different biotic compartments making use of stable isotope tracing techniques. To isolate the effect of the tailings from deposition with natural sediment an additional experimental treatment (i.e., the deposition of dead sediment) was included in the experimental setup.

We hypothesized that (I) Exposure to burial with mine tailings will alter the benthic community structure on the short term due to mortality and changes in vertical community distribution; (II) Changes in benthic community structure due to tailings disposal will cause a reduced processing of organic matter as assessed from $\mathrm{O}_{2}$ consumption, ${ }^{13} \mathrm{C}$-labeled phytodetritus uptake and production of dissolved inorganic carbon and (III) The response of benthic organisms to tailings is different than to a deposition event with natural subsurface sediment.

\section{MATERIALS AND METHODS \\ Study Site and Sediment Collection}

Sediments were collected from $207 \mathrm{~m}$ depth in the Norwegian Hadangerfjord $\left(59^{\circ} 43.48^{\prime} \mathrm{N}, 5^{\circ} 24.18^{\prime} \mathrm{E}\right.$, SW Norway) on board MS Solvik (October 28,2014$)$. Three sediment cores $(\sim 14 \mathrm{~cm})$ were subsampled from 14 boxcore deployments with a total of 42 subsampled sediment cores. The cores were transported to the laboratory at the International Research Institute of Stavanger (IRIS, Norway) and maintained in the dark at in-situ temperature $\left(8^{\circ} \mathrm{C}\right)$ for acclimatization. The cores were continuously supplied with fresh, cooled and sand-filtered seawater (salinity: 33.02) from a nearby fjord by a flow-through system via gravity feed. Twelve cores were randomly assigned to the following treatments $(n=4): 0.1,0.5$, and $3 \mathrm{~cm}$ of mine tailing (MT) addition. Six cores were assigned to the following treatments $(n=3): 0.5$ and $3 \mathrm{~cm}$ dead sediment (DS) addition. Inert, ground up tailings from a Norwegian iron ore mine were used for the MT treatments. For the DS treatment, subsurface sediment $(<20 \mathrm{~cm})$ was taken from the boxcores, temporarily frozen $\left(-80^{\circ} \mathrm{C}\right.$ for more than 3 days) to kill fauna and thawed prior to application. Four cores served as controls, i.e., no tailings or sediment was added. The remaining cores were used to measure granulometry of the natural sediment, for nematode staining tests and to determine the necessary amount of substrate required to build up to the target deposition thickness. The latter was experimentally determined as follows: Slurries of tailings and sediment were made from a known amount of material with the estimate to build $1 \mathrm{~cm}$ and were added to two separate spare cores. After $24 \mathrm{~h}$ of settlement the actual sediment height was measured and more tailings/sediment was added until a total build-up of $10 \mathrm{~cm}$. From this information the required amount of tailings/sediment was calculated.

\section{Experiment Set-Up and Incubation Procedure}

To start the experiment, the respective amounts of substrate were added to the cores and were left for $24 \mathrm{~h}$ to allow settlement of particles. The different treatment thicknesses of the tailings addition could be easily distinguished from the Control (Figure 1A) with visual inspection as the mine tailings formed a dense, gray-reddish layer with a separation of fine, light particles on top and coarser, darker particles below (Figures 1B-D). This distinction was less clear for the dead sediment addition treatments (Figures 1E-F).

The incubation procedure involved a series of manipulations, measurements, and samples obtained at the various time points throughout the incubation duration of 11 and 16 days for the MT and DS treatments, respectively (Figure 2).

After substrate addition at T0, particles were allowed to settle for $24 \mathrm{~h}$. One day after tailing addition (T1) the overlying water in the cores was clear indicating that full settlement of particles had taken place and oxygen penetration depth (OPD) in the sediment was determined. At day 8 (T8) and day 13 (T13) for MT and DS, respectively, rates of sediment community oxygen consumption (SCOC) were determined followed by a second OPD measurement. Subsequently, at day 9 (T9) for the MT and day 14 (T14) for the DS treatments, $31 \mathrm{mg}$ (equivalent to $47 \mathrm{mmol}$ $\mathrm{C} \mathrm{m}^{-2}$ ) dried Skeletonema costatum, that was enriched in ${ }^{13} \mathrm{C}$ ( $28 \%$ enrichment), was pipetted homogenously on the sediment surface in the cores and SCOC was measured once again. The isotopically enriched algae provided a tool to trace ${ }^{13} \mathrm{C}$ carbon throughout the benthic assemblage and enable quantification of fresh organic carbon processing. At day 10 (T10) for the MT treatments and day 15 (T15) for the DS treatments the experiment was terminated by sampling the sediment for faunal and sediment analyses. The different incubation durations for the two treatments are the result of logistic difficulties.

The Control followed the same time frame and sampling procedures as the MT treatments, thus, with an incubation time of 11 days.

After the experiment, sediments were sampled by inserting a smaller meiofauna core $(\sim 5 \mathrm{~cm})$ into the experimental core and the overlying water in the experimental cores was carefully siphoned off. The sediment surrounding the meiofauna core was sliced in three intervals $(0-2,2-5$, and 5-10 cm) measured from the surface of the added substrate. Each layer was homogenized in a bucket and subsamples were taken with $30 \mathrm{~mL}$ syringes and immediately stored frozen at $-21^{\circ} \mathrm{C}$ for analysis of sediment characteristics (porosity, total organic carbon, particulate organic 

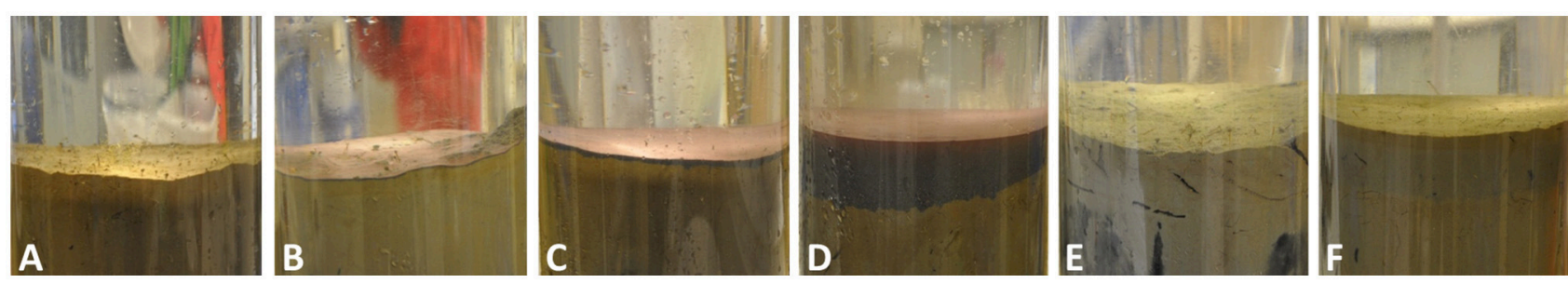

FIGURE 1 | Surface layers of the incubation cores $24 \mathrm{~h}$ after deposition. (A) Control (B) $0.1 \mathrm{~cm}$ mine tailings (C) $0.5 \mathrm{~cm}$ mine tailings (D) $3 \mathrm{~cm}$ mine tailings (E) $0.5 \mathrm{~cm}$ dead sediment $\mathbf{( F )} 3 \mathrm{~cm}$ dead sediment.

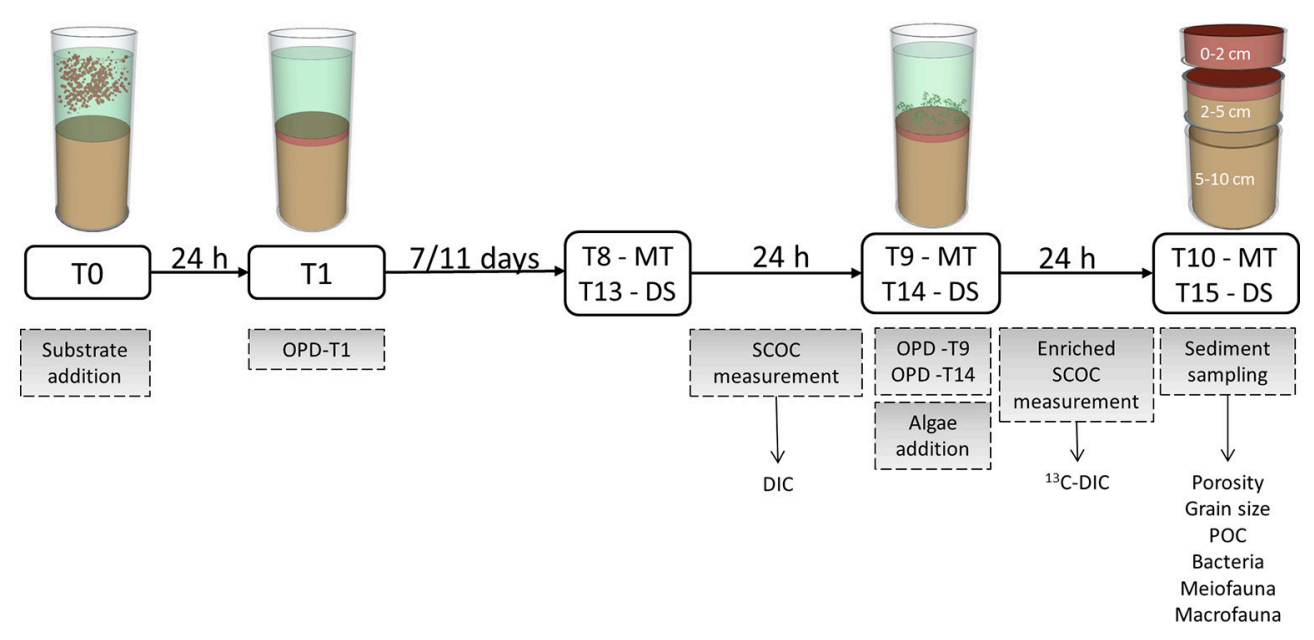

FIGURE 2 | Scheme of manipulations and samplings during the experiment. Treatments included the addition of mine tailings (MT) with $0.1,0.5$, and $3 \mathrm{~cm}$ thickness and the addition of dead sediment (DS) with 0.5 and $3 \mathrm{~cm}$ thickness. "T" Indicates the days of incubation after substrate addition. Actions and measurements are shown in gray boxes while arrows indicate from which measurements the different variables were obtained. Abbreviations: OPD, Oxygen penetration depth; SCOC, Sediment community oxygen consumption; DIC, Dissolved inorganic carbon; POC, Particulate organic carbon.

carbon) and bacterial specific phospholipid-derived fatty acids (PLFA). Sediment porosity was determined for each treatment and sediment layer by weight loss after freeze-drying. The sediment granulometry of two separate control cores, each sliced in $0.5 \mathrm{~cm}$ intervals and of one mine tailings sample were measured by laser diffraction with a Malvern Mastersize 2000 particle analyzer (Malvern Instruments, UK). Grain size classes were determined according to the Wentworth scale (Wentworth, 1922). After acidification, total organic carbon content (TOC) was quantified with a Thermo Flash EA 1112 elemental analyzer (Thermo Fisher Scientific, USA).

\section{Analyses Determining Structural Changes of the Benthic Community}

The remaining sediment from the experimental core was sieved over a 500 and $38 \mu \mathrm{m}$ sieve. The macrofauna fraction ( $>500 \mu \mathrm{m}$ ) was qualitatively screened under a stereomicroscope ("life-check," see Moodley et al., 1997) before fixation in 4\% formaldehyde to avoid abundance overestimates which could result from the lack of decomposition of dead organisms under low temperature conditions in a short-term experiment. In all samples, all encountered macrofauna specimens were found to be alive. The preserved samples were later identified to the lowest taxonomic level.

After siphoning off the overlying water of the meiofauna core, the sediment was sliced in intervals of $0.5 \mathrm{~cm}$ starting from the surface of the added substrate down to $2 \mathrm{~cm}$ depth of the natural sediment and in $1 \mathrm{~cm}$ intervals down to $5 \mathrm{~cm}$ depth. After slicing of the meiofauna cores, 5 or $10 \mathrm{~mL}$ of $4 \%$ Trypan blue solution (see Section Nematode Staining Test) were added to the 0.5 and $1 \mathrm{~cm}$ sediment slices, respectively, and samples were shaken vigorously before incubation for $2 \mathrm{~h}$ in sampling vials to ensure sufficient exposure with the stain. Subsequently, the samples were washed with filtered $(10 \mu \mathrm{m})$ seawater on a $32 \mu \mathrm{m}$ sieve until most of the stain was washed out and fixed on $4 \%$ buffered formaldehyde. Meiofauna was extracted from the sediment by washing the samples over two stacked sieves of $1 \mathrm{~mm}$ and $32 \mu \mathrm{m}$. The $32 \mu \mathrm{m}$ fraction was subjected to density centrifugation with Ludox HS40 (Dupont) at 3,000 rpm [specific density of 1.18, (Heip et al., 1995)]. Centrifugation was done three times and the supernatant was sieved $(32 \mu \mathrm{m})$ and fixed in $4 \%$ buffered formaldehyde. Meiofauna was identified to higher taxon level with a stereomicroscope (50x magnification) and nematodes were categorized in "stained" and "unstained". Copepods and their nauplii were removed from the analysis because those taxa 
were found after sieving $(32 \mu \mathrm{m})$ the seawater from the flow through system for $30 \mathrm{~min}$. This may point toward the ability of copepods and nauplii to penetrate or inhabit the sand filter. No other meiofauna taxa or larger organisms were found after sieving the water. No meiofauna was found when checking a $30 \mathrm{~mL}$ subsample of mine tailings.

Biomass of the three biotic size classes (macrofauna, meiofauna, bacteria) is expressed as organic carbon content per area $\left(\mathrm{mg} \mathrm{C} \mathrm{m} \mathrm{m}^{-2}\right.$ ) and was directly calculated from the ratio mass spectrometer output (see Section Analyses Determining Functional Changes of the Benthic Community for Full Description).

\section{Nematode Staining Test}

Trypan blue is a dye commonly used in cell viability assessments (Louis and Siegel, 2011) that has already been successfully applied to assess soil nematode mortality (Womersley and Ching, 1989). In order to assess nematode mortality, a new staining protocol with Trypan blue was developed and tested prior to the experiment. To test the protocol, the upper $1.5 \mathrm{~cm}$ of two spare cores were sliced in $0.5 \mathrm{~cm}$ intervals and three sample vials containing slices of one core were submerged in hot water $\left( \pm 80^{\circ} \mathrm{C}\right)$ for 10 minutes to kill the meiofauna. After $2 \mathrm{~h}$, all samples (dead and live) were stained with $3 \mathrm{~mL}$ of $4 \%$ Trypan blue solution (prepared with distilled water) and left to incubate for $2 \mathrm{~h}$. In the live samples $16.42 \% \pm 6.84$ of nematodes were stained while in the dead samples this percentage was $77.75 \% \pm$ 7.97. However, a proportion of $7.05 \% \pm 1.13$ and $13.27 \% \pm 4.77$ of the nematodes in live and dead samples, respectively, were left "uncategorized" due to an incomplete staining of the bodies.

\section{Analyses Determining Functional Changes of the Benthic Community}

Oxygen penetration depth (OPD) was determined by means of a microprofiler equipped with oxygen microsensors (50 $\mu \mathrm{m}$ tip; Unisense A.S., Denmark). After 2-point sensor calibration (0\% calibration: $\mathrm{Na}_{2} \mathrm{SO}_{3} ; 100 \%$ calibration: air-bubbled seawater), oxygen concentration in each core (1 profile per core) was measured by penetrating in $100 \mu \mathrm{m}$ steps into the sediment until oxygen concentration was below detection limit $(0.3 \mu \mathrm{M})$.

SCOC was measured over a $24 \mathrm{~h}$ period in the dark in cores that were sealed off with lids that were fitted with a stirrer and an oxygen optode (PreSens, Germany). During this period the cores were disconnected from the water flow through system. Water samples of $10 \mathrm{~mL}$ (filtered through a $0.2 \mu \mathrm{m}$ filter and conserved by the addition of $10 \mu \mathrm{L} \mathrm{HgCl}_{2}$ ) were taken in headspace vials at the beginning and at the end of the incubation for later analysis of the dissolved inorganic carbon (DIC) flux and ${ }^{13} \mathrm{C}$ DIC measurements. For these analyses a headspace of $\sim 1.5 \mathrm{ml}$ was created by injecting Helium gas through a septum. The samples were subsequently acidified with $20 \mu \mathrm{L}$ concentrated $\mathrm{H}_{3} \mathrm{PO}_{4}$ to transform DIC into gaseous $\mathrm{CO}_{2}$. A $500 \mu \mathrm{L}$ sample of the $\mathrm{CO}_{2}$ was then injected into a HP 61530 gas chromatograph (Hewlett-Packard/Agilent, USA) connected to a DELTA-Plus Isotope Ratio Mass Spectrometer (Thermo Fisher Scientific, USA) to determine DIC concentrations and ${ }^{13} \mathrm{C}$ composition as described by Moodley et al. (2000a). The ${ }^{13} \mathrm{C}$ composition in the freeze-dried, grinded sediment subsamples was quantified with a Thermo Flash EA 1112 elemental analyzer (Thermo Fisher Scientific, USA) coupled with an DELTA V Advantage Isotope Ratio Mass Spectrometer (Thermo Fisher Scientific, USA).

The $>500 \mu \mathrm{m}$ macrofaunal fraction was grouped in the following taxonomic groups: Echinodermata, Mollusca, Polychaeta, Sipunculida. Within each sample, each taxonomic group was individually freeze-dried to determine total dry weight. After homogenization, a weighted subsample was taken for isotope and biomass analysis (as described above for sediment, e.g., Moodley et al., 2005). In two samples, one individual or pieces of a sea pen (Pennatulacea) were found which were removed from the stable isotope analysis. The meiofauna fraction $(>38 \mu \mathrm{m})$ of the experimental core sediment was fixed on $4 \%$ buffered formaldehyde for stable isotope analysis of nematodes. For this purpose 130 randomly hand-picked nematodes per sample were transferred to a few drops of Milli-Q water in silver capsules $(8 \times 5 \mathrm{~mm})$ that had been pre-combusted for $4 \mathrm{~h}$ at $450^{\circ} \mathrm{C}$. The nematode samples were dried overnight at $60^{\circ} \mathrm{C}$, acidified with $20 \mu \mathrm{l} 2 \% \mathrm{HCl}$ and dried on a hot plate at $60^{\circ} \mathrm{C}$. After acidification the samples were closed and bulk $\mathrm{C}$ and $\mathrm{N}$ content as well as $\delta^{13} \mathrm{C}$ and $\delta^{15} \mathrm{~N}$ were measured as described for the sediment.

Bacterial tracer uptake and biomass was based on concentrations of bacteria specific PLFA (i14:0, i15:0, a15:0,

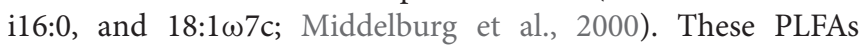
were extracted from freeze-dried, grinded sediment using the Bligh and Dyer method (Bligh and Dyer, 1959) according to the protocol by Boschker (2004). Subsequently the extracted PLFAs were derivatized to fatty acid methyl esters (FAME) that were analyzed by GC/C-IRMS (HP 61530 gas chromatographer, Hewlett-Packard/ Agilent, USA; DELTA-Plus Isotope Ratio Mass Spectrometer, Thermo Fisher Scientific, USA) with a polar analytical column (ZB5-5MS; $60 \mathrm{~m}$ length, $0.32 \mathrm{~mm}$ diameter, $0.25 \mu \mathrm{m}$ film thickness; Phenomenex, USA).

The incorporation of ${ }^{13} \mathrm{C}$ into macrofaunal, nematode and bacterial biomass was calculated as described by different papers (Middelburg et al., 2000; Moodley et al., 2002; van Oevelen et al., 2006a; Guilini et al., 2011). Total algal tracer uptake is expressed as the quotient of total ${ }^{13} \mathrm{C}$ uptake (I) and the ${ }^{13} \mathrm{C}$ content in $S$. costatum (28\%) (see Moodley et al., 2002).

\section{Statistical Analyses}

To include the depth dependency of samples, all data sets containing depth information were analyzed using a Permanova analysis with a nested design allowing statistical comparison between treatments and within depth layers (Primer software version 6.1.11 with the Permanova+ add-on, Clarke and Gorley, 2006; Anderson et al., 2008). Table 1 shows the Permanova designs for the various variables. When the main test yielded significant differences pairwise tests were performed and, if the number of possible permutations was lower than 100, Monte Carlo tests were applied to estimate $p$-values $(\mathrm{p}(\mathrm{MC})$ ) with increased accuracy. Graphs were computed using Prism 6 (GraphPad Software, Inc.). Throughout the manuscript, data is reported as mean and standard error, unless mentioned otherwise. 
TABLE 1 | Permanova designs for the analysis of various parameters.

\begin{tabular}{llll}
\hline Parameter & Factor & Nested in & Fixed/Random \\
\hline $\begin{array}{l}\text { Porosity, TOC } \\
\begin{array}{l}\text { Faunal densities, diversity and } \\
\text { community structure }\end{array}\end{array}$ & $\begin{array}{l}\text { Treatment } \\
\text { Depth }\end{array}$ & Fixed \\
$\begin{array}{l}\text { Biomass of macrofauna, } \\
\text { meiofauna and bacteria }\end{array}$ & Core ID & Treatment & Random \\
$\begin{array}{l}\text { Uptake of macrofauna, } \\
\text { nematodes and bacteria }\end{array}$ & & & \\
\hline OPD; SCOC & & & \\
& Treatment & & Fixed \\
& Time & Fixed \\
& Core ID & Treatment & Random \\
\hline
\end{tabular}

As grain size was measured in one spare core it was not analyzed statistically. Porosity and TOC were tested with Permanova for differences between treatments and the control within each layer.

Standardized densities in individuals per $\mathrm{m}^{2}$ and individuals per $10 \mathrm{~cm}^{2}$ were used for macro- and meiofauna analysis, respectively. Total (whole core) meiofauna and macrofauna densities were analyzed using ANOVA in R (R.Core Team, 2013) to assess differences between treatments after the assumptions of normality and homogeneity of variances were assured. Pairwise comparisons were conducted by means of the TukeyHSD test. For reasons of better comparison, statistical analyses were done on data from the sediment intervals of $0-2,2-$ 5 , and $5-10 \mathrm{~cm}$ starting at the added substrate surface for macrofauna and bacteria and on $0-2$ and $2-5 \mathrm{~cm}$ intervals for meiofauna. Nematode distribution and mortality on a high depth interval resolution was analyzed graphically and descriptively. The contribution of specific macro- and meiofauna taxa to differences in their community composition was determined by a similarity of percentages (SIMPER) analysis. Shannon and Simpson diversity indices and Pielou's evenness index were calculated for meio- and macrofauna densities and tested in terms of whole core diversity (ANOVA) and per depth layer (Permanova).

Due to the repeated measures character of OPD and SCOC data a Permanova analysis was used to test for differences between the factors Treatment and Time (Permanova design, Table 1). Univariate data of DIC was analyzed using ANOVA to assess differences between treatments after the assumptions of normality and homogeneity of variances were assured. Total (whole core) tracer uptake of the different biotic compartments was analyzed with Permanova as assumptions for normality and homogeneity of variances were not met. Depth layer information was included with Permanova as described above.

\section{RESULTS}

\section{Effect of Substrate Addition on Abiotic Variables}

The natural sediment was composed of fine silt characterized by a median grain size of $11.94 \pm 0.34 \mu \mathrm{m}$ in the $0-2 \mathrm{~cm}$ layer, $12.26 \pm 0.13 \mu \mathrm{m}$ in the $2-5 \mathrm{~cm}$ layer and $12.59 \pm 0.56 \mu \mathrm{m}$ in the $5-10 \mathrm{~cm}$ layer. In contrast, the mine tailings were composed of very fine sand with a median grain size of $101.31 \mu \mathrm{m}$. The difference in median grain size between the mine tailings and the natural sediment was also reflected in the lower porosity of the added layers of tailings compared to the natural sediment [Permanova, $\mathrm{p}(\mathrm{MC}) \leq 0.003$ Figure 3A]. Additionally, TOC was lower in the layers with added tailings compared to control cores [Permanova, $\mathrm{p}(\mathrm{MC}) \leq 0.013$, Figure 3B] .

\section{Structural Changes of the Benthic Community}

Total macrofauna densities ranged from $12,971 \pm 3,573$ ind. $\mathrm{m}^{-2}$ in the 3 DS treatment to $20,040 \pm 2,780$ ind. $\mathrm{m}^{-2}$ in the 0.1 MT treatment. Though total densities did not significantly differ between treatments, a decreasing trend with sediment depth was observed. Within each sediment depth layer community composition was similar between treatments and control. Within each mine tailings treatment and the control, the community composition in the $0-2 \mathrm{~cm}$ layer was different from the deeper layers [Permanova, $\mathrm{p}(\mathrm{MC}) \leq 0.0400$ ]. Main contributors to the dissimilarities between the $0-2$ and $2-5 \mathrm{~cm}$ and between the $0-2$ and 5-10 cm layers were Kelliella militaris (bivalve, 6.5\%, 7.23\%), Macrochaeta sp. (polychaete, $4.11 \%, 4.45 \%$ ), Ophelina modesta (polychaete, 3.39\%, 3.84\%), Mendicula pygmaea (bivalve, 3.27\%, $3.54 \%)$, Sipuncula sp. $(2.14 \%, 4.05 \%)$ and Nucula nitidosa (bivalve, $2.83 \%, 3.46 \%$ ) with much higher densities in the top (0$2 \mathrm{~cm}$ ) layer and Paramphinome jeffreysii (polychaete, $4.26 \%, 3.67$ $\%$ ) and Levinsenia gracilis (polychaete, 2.27\%, 3.67\%) showing the opposite trend. This depth effect in community composition was not observed in the DS treatments, thus, all organisms were distributed similarly throughout those cores.

Total meiofauna densities (including stained and unstained nematodes) were significantly lower $\left(712 \pm 252\right.$ ind. $\left.10 \mathrm{~cm}^{-2}\right)$ in the 3 DS treatment compared to the control $(2080 \pm 93$ ind. $10 \mathrm{~cm}^{-2}$, TukeyHSD, $\left.p=0.0115\right)$. This difference was attributed to a reduction in nematode densities (TukeyHSD, $p$ $=0.0105)$ which was the most abundant taxon $(94.91 \pm 0.34$ $\%$ of meiofauna community). Nematodes were found in high densities in all surface layers, indicating that the animals were able to move into the added MT and DS substrate (Figure 4). Interestingly, mortality in the MT treatment was substantially higher as compared to the controls (Figure 4), with mortality exceeding $80 \%$ in the $0.5 \mathrm{MT}$ and $3 \mathrm{MT}$ treatment. Furthermore, mortality in the 3 DS treatment was high throughout the whole core and not only in the added substrate layer (17.74-63.56\%). The addition of mine tailings had no effect on the whole-core meiofauna community composition (faunal mortality not taken into account). In both DS treatments, however, it differed from the control [Permanova, $\mathrm{p}($ perm $) \leq 0.0073$ ] due to reduced densities of nematodes, oligochaetes, and polychaetes (SIMPER). When taking depth layers into account we observed that all taxa were equally successful in migrating into the mine tailings since community composition remained similar in the Control and MT treatments within the upper $2 \mathrm{~cm}$. Also within the deeper layer $(2-5 \mathrm{~cm})$ meiofauna community composition remained similar in all treatments when compared to the 

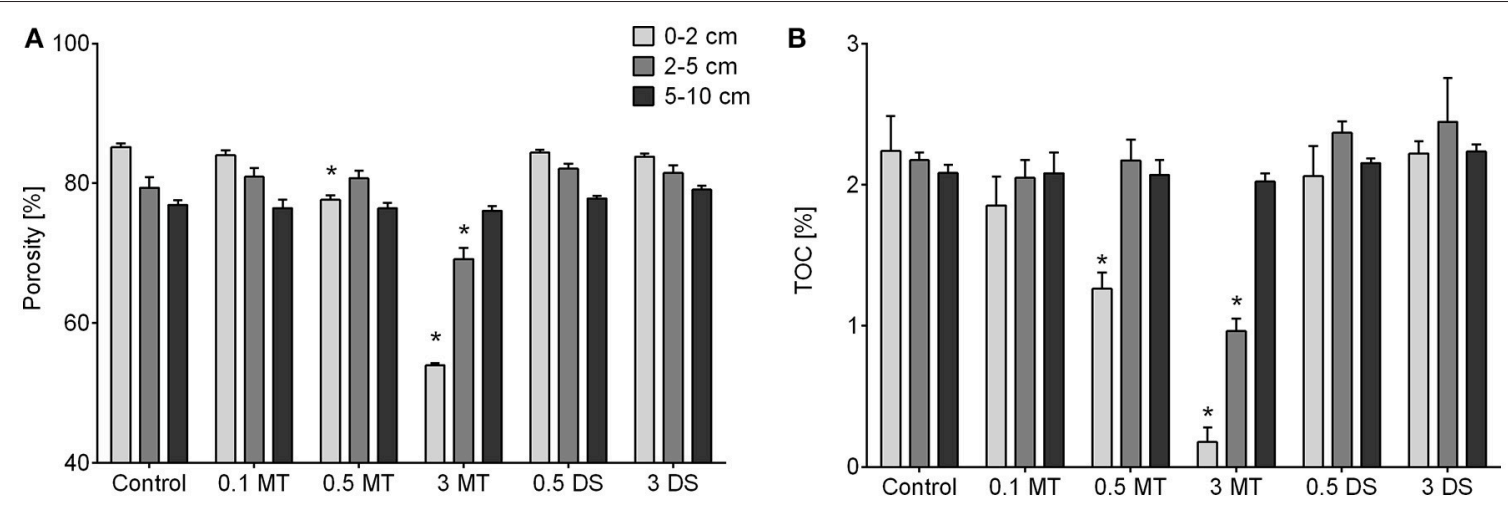

FIGURE 3 | (A) Porosity and (B) total organic carbon (TOC) content of all depth layers per treatment. Error bars denote standard error and an asterisk indicates significant $(p<0.05)$ differences with the control. Abbreviations: $0.1 \mathrm{MT}=0.1 \mathrm{~cm}$ mine tailing addition, $0.5 \mathrm{MT}=0.5 \mathrm{~cm}$ mine tailing addition, $3 \mathrm{MT}=3 \mathrm{~cm}$ mine tailing addition, $0.5 \mathrm{DS}=0.5 \mathrm{~cm}$ dead sediment addition, $3 \mathrm{DS}=3 \mathrm{~cm}$ dead sediment addition.

Control [Permanova, $\mathrm{p}$ (perm) $\leq 0.0162$ ]. Interestingly, within each treatment, meiofauna community composition differed between depth layers $(0-2$ and $2-5 \mathrm{~cm})$ for all treatments except the 3 MT and 3 DS treatments [Permanova, $\mathrm{p}(\mathrm{MC}) \leq$ 0.049]. Differences could be attributed to lower abundances of Kinorhyncha, Ostracoda, Nematoda, and Polychaeta in the 2$5 \mathrm{~cm}$ layer (SIMPER). Overall meiofauna higher taxon diversity and evenness were low and did not differ between treatments with the exception that evenness was significantly higher in the upper layer of the 3 DS treatment compared to the control due to reduced nematode densities and, thus, reduced dominance of this taxon. Diversity and evenness did not differ between treatments.

In the control situation, total biomass was highest for bacteria $\left(9824.93 \pm 1503.20 \mathrm{mg} \mathrm{C} \mathrm{m}^{-2}\right)$ followed by macrofauna $(716.47$ $\pm 109.45 \mathrm{mg} \mathrm{C} \mathrm{m}^{-2}$ ) and nematodes (413.67 $\pm 90.01 \mathrm{mg} \mathrm{C} \mathrm{m}^{-2}$; Figure 5). The high variability in macrofaunal biomass did not reveal any differences between treatments or depth. For bacteria and nematodes, however, the addition of $3 \mathrm{~cm}$ of mine tailings resulted in a reduced biomass in the $0-2 \mathrm{~cm}$ layer compared to the control [Permanova, $\mathrm{p}(\mathrm{MC}) \leq 0.0341$ ]. Furthermore, nematode biomass was reduced in the upper layer of the 3 DS treatment and the $2-5 \mathrm{~cm}$ layer of the $0.5 \mathrm{MT}$ treatment [Permanova, $\mathrm{p}(\mathrm{MC}) \leq$ $0.0197]$.

\section{Functional Changes of the Benthic Community}

Under control conditions oxygen penetrated $1.17 \pm 0.11 \mathrm{~cm}$ deep into the sediment at the start of the experiment and remained stable throughout the experiment (Figure 6). The OPD of the 3 $\mathrm{cm}$ mine tailings treatment was $2.98 \pm 0.54 \mathrm{~cm}$, which means that oxygen did not reach beyond the tailings, leaving the natural sediment anoxic. Moreover, the OPD decreased to $1.49 \pm 0.18$ $\mathrm{cm}$ at the end of the experiment [Permanova, $\mathrm{p}($ perm $)=0.0098$ ]. The deposition of dead sediment resulted in a shallower OPD compared to the Control $(0.61 \pm 0.05 \mathrm{~cm}$ and $0.57 \pm 0.06$ $\mathrm{cm}$ for $0.5 \mathrm{DS}$ and $3 \mathrm{DS}$, respectively) after the deposition event [Permanova, $\mathrm{p}(\mathrm{MC}) \leq 0.036$ ], but gradually deepened and approached control conditions at the end of the experiment.
After 8 (MT) and 13 (DS) days of incubation, the sediment community oxygen consumption (SCOC) was reduced in the 0.5 and 3 MT treatments compared to the Control [Permanova, $\mathrm{p}($ perm $) \leq 0.0236]$ while in the 3 DS treatment SCOC increased [Permanova, $\mathrm{p}($ perm $)=0.0342$, Figure 7]. The SCOC increased in all treatments after addition of the algal tracer [Permanova, $\mathrm{p}($ perm $)=0.0001$, Figure 7].

A large fraction of $85.21 \pm 1.40 \%$ of the added algal carbon was not processed and remained in the form of particulate organic carbon (POC) in the sediment, especially in the $0-2 \mathrm{~cm}$ layer (Figure 8A). Of the added algal carbon $9.70 \pm 1.01 \%$ was respired into dissolved inorganic carbon (DIC; Figure 8B). No significant differences in total ${ }^{13} \mathrm{C}$-POC or algal ${ }^{13} \mathrm{C}$-DIC were found between treatments.

Total tracer- $\mathrm{C}$ uptake was reduced in the 3 MT treatment for nematodes and macrofauna (Permanova, $p \leq 0.0038$ ) and for bacteria (Permanova, $p=0.0523$, borderline significant, Figures 8C-E). Additionally, uptake by nematodes was lower for the 0.5 MT, 0.5 DS, and 3 DS treatment [Permanova, $\mathrm{p}(\mathrm{MC}) \leq$ 0.0365]. When taking depth into account, a significant decrease in tracer uptake by nematodes was observed in the top layer $(0-2 \mathrm{~cm})$ of the MT and DS treatments. In general, uptake was highest in the upper $2 \mathrm{~cm}$ for bacteria and nematodes while macrofaunal uptake was high in the upper $5 \mathrm{~cm}$ with significantly lower values in the $5-10 \mathrm{~cm}$ layer $(\mathrm{p}(\mathrm{MC})<0.01)$.

\section{DISCUSSION}

With the continuing STP and prospect of new STP sites from land based mining facilities in many locations, but also with the perspective of deep-sea mineral extraction (e.g., massive sulfides and polymetallic nodules) and associated disposal of waste sediment, there is an urgent need for quantitative assessments of the environmental impact of tailings deposits in marine environments (Mengerink et al., 2014; Ramirez-Llodra et al., 2015; Levin et al., 2016). Due to the slow growth and long life spans of many deep-sea taxa (Young, 2003) they are particularly vulnerable to the impacts associated with tailings placement 

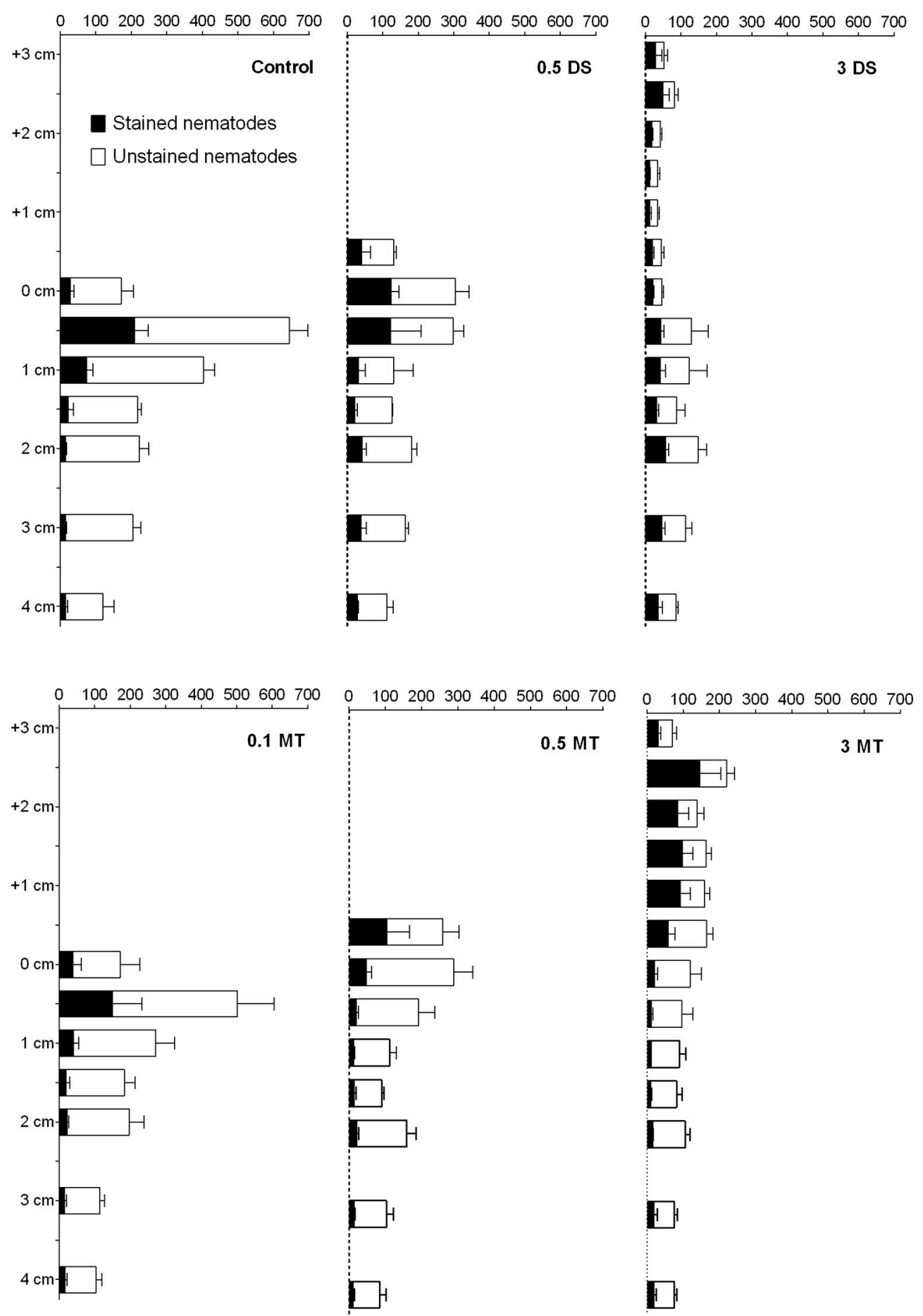

FIGURE 4 | Mean abundances (x-axis) of stained (dead) and unstained (alive) nematodes in the different substrate addition treatments. Error bars indicate standard error. Abbreviations: $0.1 \mathrm{MT}=0.1 \mathrm{~cm}$ mine tailing addition, $0.5 \mathrm{MT}=0.5 \mathrm{~cm}$ mine tailing addition, $3 \mathrm{MT}=3 \mathrm{~cm}$ mine tailing addition, $0.5 \mathrm{DS}=0.5 \mathrm{~cm}$ dead sediment addition, $3 \mathrm{DS}=3 \mathrm{~cm}$ dead sediment addition.

such as hyper sedimentation, changes in grain size, or toxicity effects (Kvassnes and Iversen, 2013). To our knowledge, this experimental study is the first of its kind to investigate the impacts of different levels of inert mine tailings and sediment deposition on both, structure and functioning, of upper bathyal soft-bottom communities. 


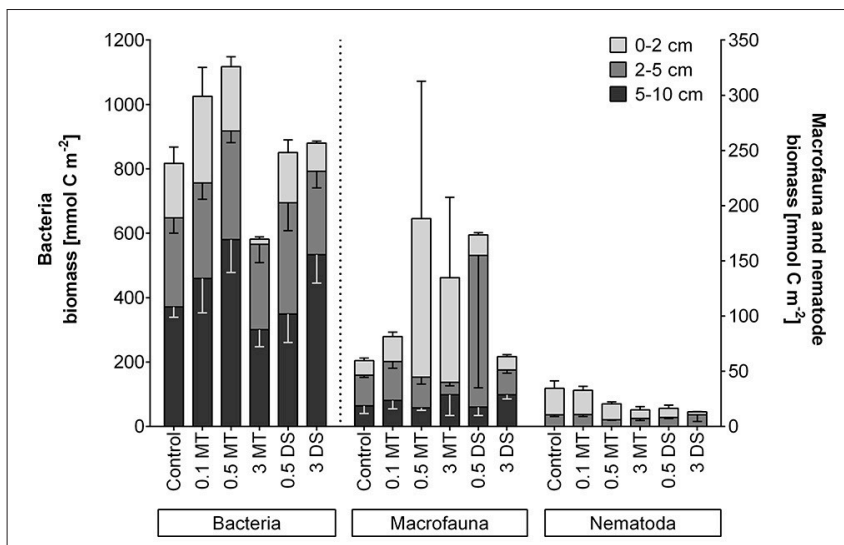

FIGURE 5 | Biomass per depth and treatment in the three biological compartments measured: Bacteria (left y-axis), macrofauna and Nematoda (right y-axis). Error bars depict standard errors and point downwards for the $2-5 \mathrm{~cm}$ and $5-10 \mathrm{~cm}$ data for better visualization. Abbreviations: $0.1 \mathrm{MT}=$ $0.1 \mathrm{~cm}$ mine tailing addition, $0.5 \mathrm{MT}=0.5 \mathrm{~cm}$ mine tailing addition, $3 \mathrm{MT}=3$ $\mathrm{cm}$ mine tailing addition, $0.5 \mathrm{DS}=0.5 \mathrm{~cm}$ dead sediment addition, $3 \mathrm{DS}=3$ $\mathrm{cm}$ dead sediment addition.

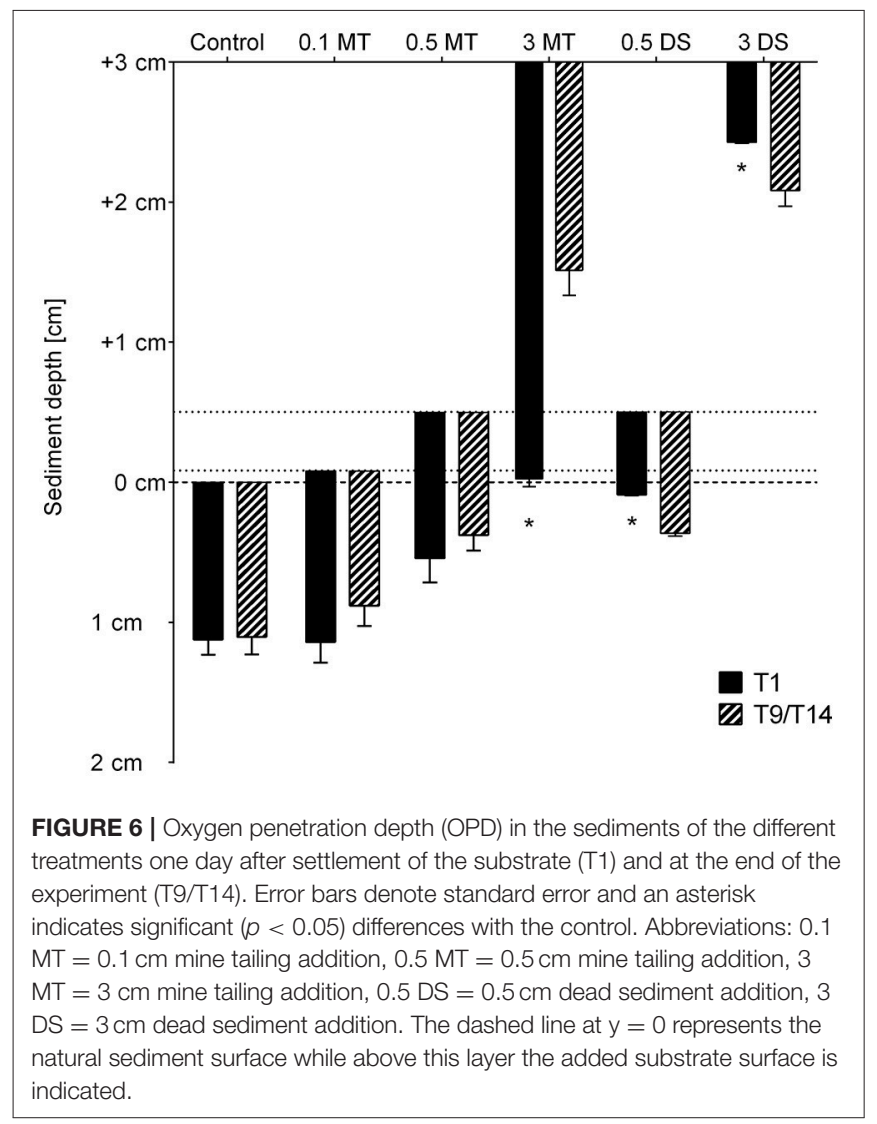

\section{Substrate Addition Induces Structural Changes of the Benthic Community}

Sediment characteristics substantially determine the composition of benthic assemblages and while meiofauna communities are

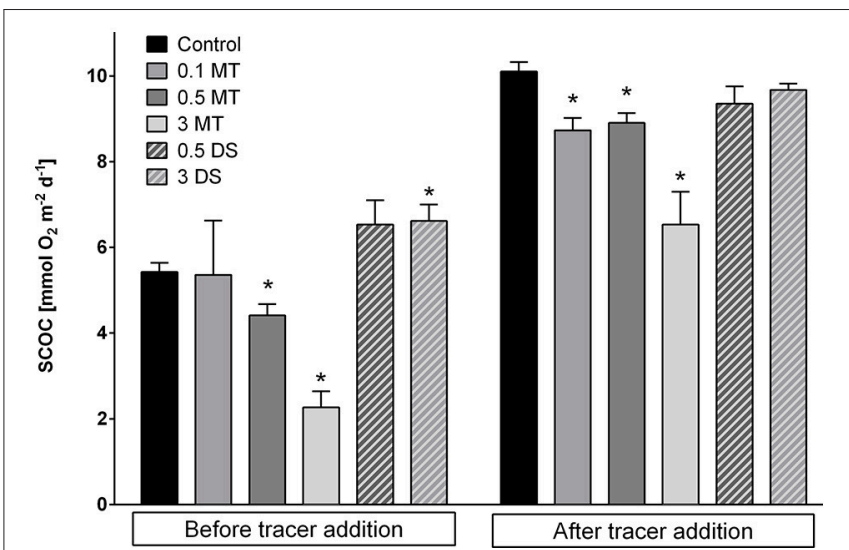

FIGURE 7 | Mean sediment community oxygen consumption (SCOC) in mmol $\mathrm{O}_{2} \mathrm{~m}^{-2} \mathrm{~d}^{-1}$ before and after tracer addition for the different substrate addition treatments. Error bars denote standard error and an asterisk indicates significant $(p<0.05)$ differences with the control. Abbreviations: $0.1 \mathrm{MT}=$ $0.1 \mathrm{~cm}$ mine tailing addition, $0.5 \mathrm{MT}=0.5 \mathrm{~cm}$ mine tailing addition, $3 \mathrm{MT}=$ $3 \mathrm{~cm}$ mine tailing addition, $0.5 \mathrm{DS}=0.5 \mathrm{~cm}$ dead sediment addition, $3 \mathrm{DS}=$ $3 \mathrm{~cm}$ dead sediment addition.

strongly influenced by sediment grain size (Jansson, 1967; Coull, 1999), macrofauna community structure is most likely governed by factors of e.g., food availability, sediment oxygenation, and biotic interactions rather than grain size (Snelgrove and Butman, 1994; Seiderer and Newell, 1999). In our experiment, the physical modifications from substrate addition were visible in the different properties of the new, added substrates with much coarser grain size, lower porosity and a low TOC in the mine tailings and relatively high TOC in the dead sediment. These results confirm the successful addition of both substrates and physical modification of the upper sediment layers.

Furthermore, the addition of each of the two substrates immediately changed oxygen conditions in the natural sediment. The two most extreme treatments (3 MT and 3 DS) resulted in anoxic conditions of the natural sediment throughout the entire experiment duration. The first hypoxia related response of benthic invertebrates is migration to more suitable areas in the sediment, although successful migration strongly depends on the mobility of the individual taxa or species and the properties of the added substrate (e.g., grain size, porosity; Jansson, 1967; Maurer et al., 1986; Hendelberg and Jensen, 1993; Diaz and Rosenberg, 1995; Wetzel et al., 2001). Accordingly, we observed migration into the added substrate of most metazoan taxa and an upward shift in meio- and macrofauna community composition in all treatments. Successful migration of benthic organisms into added, non-native substrates is well-known (Maurer et al., 1986; Schratzberger et al., 2000; Bolam, 2011), however, the upward shift in our experiment was accompanied by a high nematode-mortality in both substrate additions. Without the applied nematode staining technique this observation would have been missed and the impacts of substrate addition on nematodes would have been underestimated.

In the mine tailings, nematode mortality was possibly linked to a strongly reduced food availability. Compared to other taxa, 

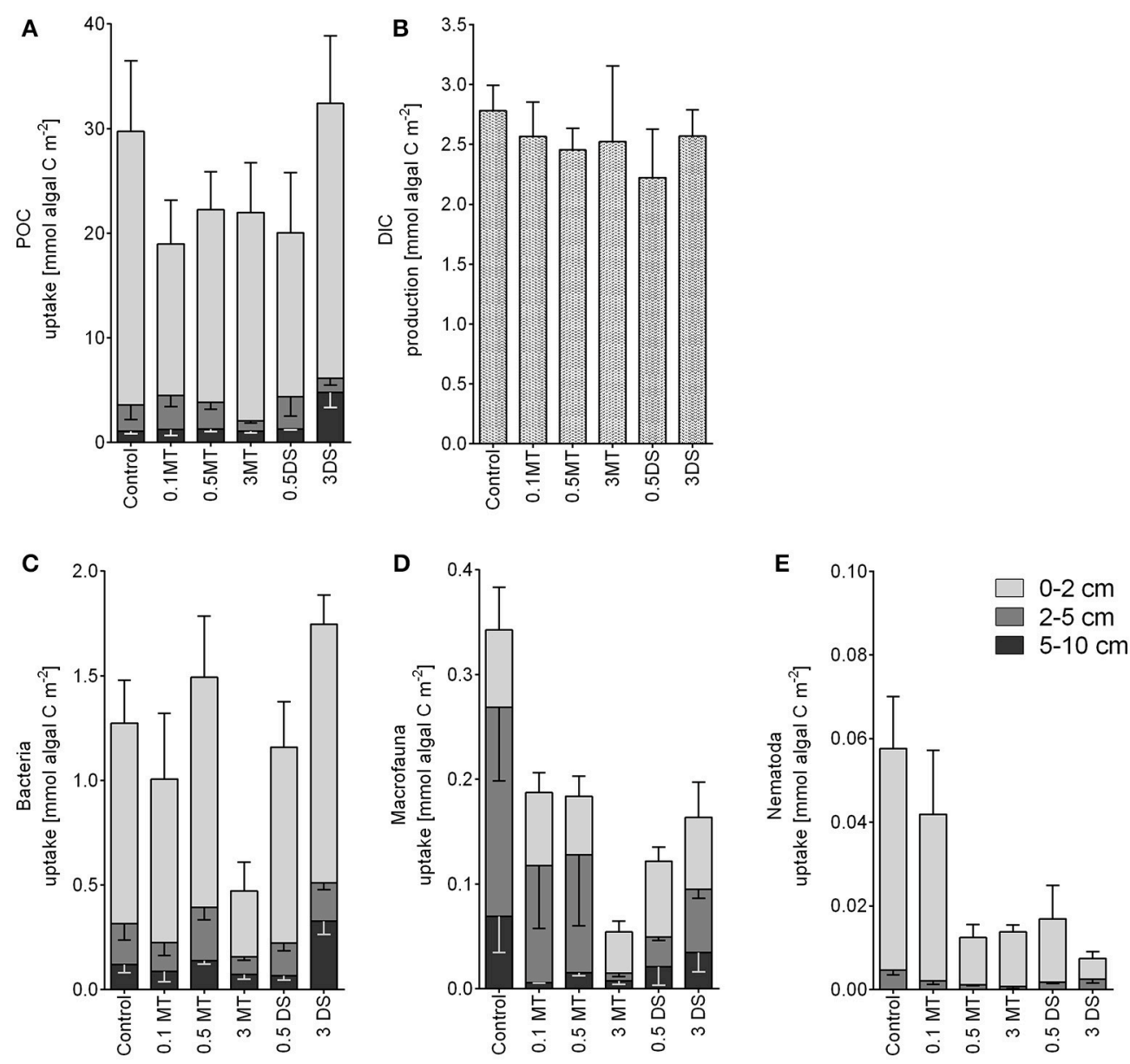

FIGURE 8 | Particulate organic carbon (POC, A) per treatment and depth; (B) dissolved inorganic carbon (DIC, B) per treatment; and uptake of algal ${ }^{13} \mathrm{C}$ per depth and treatment of (C) Bacteria, (D) Macrofauna and (E) Nematoda. Error bars depict standard errors and point downwards for the $2-5 \mathrm{~cm}$ and $5-10 \mathrm{~cm}$ data for better visualization. Abbreviations: $0.1 \mathrm{MT}=0.1 \mathrm{~cm}$ mine tailing addition, $0.5 \mathrm{MT}=0.5 \mathrm{~cm}$ mine tailing addition, $3 \mathrm{MT}=3 \mathrm{~cm}$ mine tailing addition, $0.5 \mathrm{DS}=0.5 \mathrm{~cm}$ dead sediment addition, $3 \mathrm{DS}=3 \mathrm{~cm}$ dead sediment addition.

nematodes are often reported to be able to survive situations of severe stress, such as temporary hypoxia or seawater acidification (Josefson and Widbom, 1988; Widdicombe et al., 2009; Schade et al., 2016) and the capability to change feeding modes to some extent may be advantageous in those situations (Moens and Vincx, 1997). Bacterial growth strongly depends on the availability of organic matter (Danovaro, 1996; Kirchman and Rich, 1997; Eiler et al., 2003) so despite the fact that the tailings were well oxygenated, the low organic carbon content did not support strong bacterial growth resulting in very low food availability for meio- and macrofauna inside the added layer. The survival of nematodes in low food conditions is very species dependent but generally an incubation time of 10 or more days, as applied here, is sufficient to set the worms at their limit (Ott, 1972; Ott and Schiemer, 1973; Wieser et al., 1974).

In contrast, the mechanism behind the nematode mortality and reduced densities in the DS treatment is likely different from that of the MT treatment. High bacterial biomass and total organic carbon in the added dead sediment, compared to conditions in the control, should have led to higher concentrations of food for the nematodes. Nevertheless, we observed a strong reduction in nematode densities and high proportions of dead nematodes in all layers throughout the core. Here, the cause is likely linked to the anoxic conditions in the sediment produced by the high bacterial activity in terms of carbon uptake and resulting increased oxygen demand. In a laboratory experiment with an intertidal meiofauna community, Steyaert et al. (2007) found that suboxic and anoxic conditions for 14 days led to a decrease by about a third in nematode densities with species specific survival. Similarly, other studies report hypoxia associated mortality of nematode fauna and shifts in meiofauna community composition toward hypoxia adapted species (Hendelberg and Jensen, 1993; Moodley et al., 1997; Van Colen et al., 2009; Wetzel et al., 2001). Low nematode densities in the 3 DS treatment possibly result from a combination of the high mortality and decomposition of dead nematodes, potentially also facilitated by the longer incubation time in the dead sediment treatments. 
Macrofaunal responses were less obvious and organisms showed no signs of mortality. Nevertheless, while tailings addition resulted in an upward shift of the entire macrofauna community, dead sediment addition resulted in a less clear distinction between surface and subsurface community composition, compared to the control situation. The stress response of macrofauna is species-specific and depends on their mobility, oxygen requirements, and feeding type (Chou et al., 2004; Hinchey et al., 2006; Smit et al., 2008). In a metanalysis, Smit et al. (2008) predicted from marine species sensitivity distributions that instantaneous burial with $5.4 \mathrm{~cm}$ of natural sediment would negatively affect about half of the 32 analyzed macrofauna species. Furthermore, burial with $0.63 \mathrm{~cm}$ already affected $5 \%$ of the tested macrofauna species. Substrate addition and especially tailings addition may lead to emigration or death of certain macrofaunal organisms on a longer term if requirements of oxygen and food availability are not met. While several studies on shallow water ecosystems report on the effects of burial with sediment following dredging (Bonvicini pagliai et al., 1985; De Grave and Whitaker, 1999; Thrush and Dayton, 2002; e.g., Bolam, 2011) or strong hydrodynamic disturbances (Miller et al., 2002 and citations therein; e.g., Dernie et al., 2003), we need to be cautious in comparing these results with tailings burial. Indeed, as observed in this study, the specific characteristics of tailings in terms of grain size, organic matter content and porosity (disregarding any toxicological properties) compared to the natural sediment led to differing structural responses and community functioning (see Section Community Functioning Changes as a Result of Structural Changes Induced by Substrate Deposition).

The differential response of meiofauna and macrofauna to low oxygen concentrations and starvation contradicts the general perception that the meiofauna are more resistant to different stressors than macrofauna. Many authors studying the effect of hypoxia on benthic communities report a more negative effect of long hypoxic events on macrofauna, including mortality, whereas meiofauna is generally less affected and can withstand long hypoxic events (Weigelt and Rumohr, 1986; Josefson and Widbom, 1988; Diaz and Rosenberg, 1995; Van Colen et al., 2009). However, these studies focused on hypoxia in the water column which was not the case in our experiment where the overlying water was always well oxygenated. Here, the greater capacity of macrofauna to move vertically in the sediment could have enabled organisms to reach oxygenated layers as well as food-rich surface layers ensuring their survival. The loss of distinction between the macrofaunal community composition in different depth layers in the dead sediment treatments could be a first indication to support this hypothesis. Thus, while meiofauna could not compensate the very rapid occurrence of anoxic conditions in the sediment by vertical migration, macrofauna may have been more successful in doing so.

Despite a comparatively low standing stock, the high activity and life cycle turnover rates of meiobenthic organisms make them a particularly important part of the benthic environment when it comes to biomass production and food consumption (Gerlach, 1971; Coull, 1999). Furthermore, they can exert a strong impact on other benthic organisms by enhancing bacterial productivity (Gerlach, 1978) and influencing macrobenthic species interactions which can result in modified ecosystem properties (Piot et al., 2013). Therefore, the high nematode mortality induced by substrate burial may lead to strong repercussions on other benthic organisms on a longer term.

\section{Community Functioning Changes as a Result of Structural Changes Induced by Substrate Deposition}

In this study we observed strong, negative effects of substrate addition on the benthic community structure in terms of biomass and composition. These changes led to adverse effects of benthic functioning in terms of respiration rates and organic matter processing. Oxygen is a key element in the aerobic respiration and metabolism of organisms and, thus, tightly linked to the mineralization of organic carbon and the activity of benthic organisms. Therefore, OPD and SCOC can provide a reliable indication of organic matter remineralization rates (Moodley et al., 1998) and, combined with stable isotope carbon uptake data of the biota, has proven to be a good tool to assess ecosystem functioning and responses of the benthos to environmental disturbances (Bratton et al., 2003; Sweetman et al., 2010, 2014, 2016).

Immediately after settlement of the added substrates, a shift in OPD occurred in most treatments. OPD did not decrease at 0.1 and $0.5 \mathrm{~cm}$ tailings addition but shifted upwards leaving previously oxygenated deeper sediment layers anoxic. Furthermore, despite an increase in OPD at $3 \mathrm{~cm}$ of tailings addition compared to the control, the underlying, previously oxygenated sediment became anoxic because oxygen did not penetrate through the mine tailings layer to the natural sediment anymore. Similarly, Cummings et al. (2009) observed an upward shift of the OPD when marine sediments were exposed to very thin layers of terrestrial sediments. In this study OPD (measured throughout 3 days) penetrated $\pm 0.7 \mathrm{~mm}$ in the control situation, while after the addition of $\pm 1.1 \mathrm{~mm}$ of terrestrial sediment oxygen only penetrated $\pm 0.3 \mathrm{~mm}$ into the underlying sediments. Thus, comparable to our study, organisms inhabiting the surface sediment will become exposed to a deterioration of biogeochemical conditions after the addition of a non-native substrate. In our experiment, however, OPD in the tailings treatments became shallower toward the end of the experiment possibly by a higher biogenic activity inside the tailings due to faunal migration. Sediment deposition resulted in a decreased OPD at the start of the experiment that might be linked to strong microbial respiration due to high organic matter contents of the added sediment. Also in this case, underlying sediment layers were exposed to biogeochemical changes negatively affecting structure and functioning of biota. Toward the end of the experiment OPD deepened to values comparable to the control indicating a possible stabilization of the biogeochemical conditions in the dead sediment treatments to a pre-disturbance state.

Values of SCOC in our control incubations were comparable to those reported in other studies with Norwegian fjord fauna (Ishida et al., 2013; Sweetman et al., 2014, 2016). The SCOC 
measurements after 8 and 13 days of incubation (MT and DS, respectively) informed about the effect of substrate addition on the SCOC, while the second measurement informed about the response of the sediment community to input of algal detritus. Mine tailings burial reduced oxygen consumption in the 0.5 and $3 \mathrm{~cm}$ treatments, but SCOC increased in the dead sediment treatments when compared to the control. Low organic matter content associated with low bacterial biomass and faunal mortality may explain the reduced SCOC measurements in the mine tailings treatments. On the contrary, high organic matter content and an increase in SCOC in the dead sediments may point toward increased bacterial activity as they play a key role in the carbon turnover in marine sediments (Rowe and Deming, 1985; Deming and Baross, 1993). However, in the dead sediment treatments, addition of fresh organic matter in the form of labeled algae did not lead to a pronounced increase in oxygen consumption as it did in the mine tailings treatments and the control. This is possibly due to the already high rate of organic matter processing and strong bacterial respiration resulting from the organic matter input originating from the dead sediment itself. It is important to note that SCOC increased in all treatments after algae addition but, at the same time, the negative effect of tailings addition on the processing of a new food source became more pronounced when compared to the control situation. This way even a deposition of $0.1 \mathrm{~cm}$ sufficed to induce a significant reduction in SCOC, illustrating that the benthic community was hampered to process fresh organic matter by as little as $0.1 \mathrm{~cm}$ of tailings.

Bacteria dominate deep-sea ecosystems in terms of abundance and biomass and are the main contributors to organic matter remineralization (Wei et al., 2010; Danovaro et al., 2014). Similarly, in our experiment we observed that bacteria had a higher biomass and took up considerably more added algal carbon compared to macro- and meiofauna. Interestingly, at $0.1 \mathrm{~cm}$ tailings addition, bacterial tracer uptake and biomass remained close to control conditions while a decreasing trend of tracer uptake was already visible for macro- and meiofauna. Here, the tailings layer may have posed a physical barrier for those organisms to reach the new source of organic matter present on the sediment surface. At $3 \mathrm{~cm}$ tailings addition, low bacterial biomass and possibly reduced faunal activity in terms of bioturbation lead to a lower fraction of the added algae being transported to deeper layers and an overall reduced tracer uptake. Bioturbation by infauna strongly influences ecosystem functioning, especially in sediments where disturbances are low, as it provides structure to the sediments and is responsible for irrigation, transport of nutrients and organic matter to deeper layers and providing various microhabitats for meiofauna and bacterial communities (Mermillod-Blondin et al., 2004; Meysman et al., 2006; Braeckman et al., 2010).

Continental margins are responsible of $10-15 \%$ of the global ocean primary production and fulfil an important role in the sequestration of atmospheric carbon and transport to the deepocean (Muller-Karger et al., 2005; Fennel, 2010). Furthermore, with high denitrification rates these regions adjacent to land boundaries act as a barrier for nitrogen input from land and atmosphere into the open ocean (Fennel, 2010). This disproportional contribution to the total ocean nutrient cycling is the result of tight biological interactions, biogeochemical transformations facilitated by microorganisms and characteristic hydrodynamics (Renaud et al., 2007; Hofmann et al., 2011). Therefore, disturbing these ecosystems by activities such as mine tailings placement, can have implications on a much larger scale.

\section{The Origin of the Added Substrate Results in Differential Responses}

This study clearly illustrated how both substrates used in this experiment resulted in differential responses. Mine tailings addition mainly induced food-limitation for all benthic compartments in the added layers, whereas the high bacterial respiration in the dead sediment layer initially led to oxygen limitation in deeper layers. In the sediment addition treatments, oxygen conditions seemed to return to conditions similar to the control indicating a possible biochemical recovery of the sediments to normal conditions after the 15 day period. With bacterial and macrofaunal biomass and uptake being similar to control conditions it is possible that those taxa might recover relatively fast. Meiofauna, however, suffered most in this scenario with strongly reduced densities, low carbon uptake, and increased mortality. The interconnectedness of the three benthic compartments is widely acknowledged and changes in one taxon can have strong repercussions on the other (Gerlach, 1971, 1978; Alongi and Tenore, 1985; Evrard et al., 2010; Piot et al., 2013), thus we cannot exclude the possibility of adverse effects on the long term. As a naturally occurring phenomenon, marine organisms are to some extent adapted to sedimentation and resuspension, and ecosystems may show increased resilience to sediment disturbance, particularly if they are subjected to a high intensity of natural disturbance (Schratzberger and Warwick, 1998; Leduc and Pilditch, 2013). However, man-made sedimentation events may exceed natural variability in sediment load and frequency and may induce permanent changes in the ecosystem. In the mine tailings treatments no signs of recovery of the benthic community to control conditions were observed within the experiment duration of 11 days. In fact, monitoring studies for STP have shown that after cessation of extensive tailings discharge (up to $4-5 \mathrm{~cm}$ tailings addition per year during $>20$ years) it may take 1 to 4 years before the tailings are fully recolonized while differences in community compositions still prevail (Olsgard and Hasle, 1993; Burd, 2002). However, it remains uncertain if, accompanied with faunal recovery, also ecosystem function will return to normal values. Unfortunately, controlled experiments to determine threshold levels for sediment overburden and tolerated frequencies are largely missing (Miller et al., 2002).

Our study contributes to reducing this knowledge gap since comparing different deposition depths and substrates allows us to gain some information on threshold values and differentiate the effects of substrate characteristics on benthic community structure and functioning. When applying the precautionary principle in a STP scenario, instantaneous depositions with as little as $0.1 \mathrm{~cm}$ of tailings over large areas have to be avoided to maintain ecosystem functioning in terms of organic matter 
remineralization at normal levels. Structural changes of biota with reduced biomass and shifts in vertical distribution become apparent at $0.5 \mathrm{~cm}$ burial with tailings and intensify at 3 $\mathrm{cm}$ tailings deposition. It remains unclear how fast biological communities can recover from the short-term effects and how repeated burial with tailings will affect species survival on a longer term. Furthermore, macrofauna is often used to assess and monitor environmental impacts, but was actually the most tolerant group in our experiment while the response of meiofauna was much more pronounced. Therefore, monitoring studies should make use of a more integrated approach covering multiple size groups representing different functional traits and trophic levels.

\section{CONCLUSION}

Our research clearly shows that burial with both, mine tailing or dead sediment, has strong negative effects on the biota and the functioning of benthic communities. However, the processes behind the impacts were different between the two substrate additions.

The most severe effects were observed at $3 \mathrm{~cm}$ of tailings deposition with a reduction of bacterial and meiofaunal biomass by more than half, reduced algal carbon uptake of all biological compartments and reduced sediment community oxygen consumption. However, already at $0.1 \mathrm{~cm}$ tailings deposition, the ability of the benthic community to process organic matter was significantly reduced while the structure of the community remained largely unaffected at this level. This emphasizes the importance of using multiple trophic levels and an ecosystem-based approach in laboratory experiments including measures of ecosystem functioning. The addition of dead sediment, on the other hand, resulted in an increase in bacterial activity causing severe anoxia in the underlying sediment layers entailing decreased meiofaunal biomass and changes in the vertical distribution of macrofauna. While productivity in terms of bacterial biomass and carbon turnover are enhanced on the short term, mortality of nematodes and resulting shifts in benthic community composition might induce unforeseen consequences on the longer term. While possibly less obvious in measurements of abundance, physical disturbance and changes in sediment characteristics may substantially influence infauna community composition, particularly that of meiofauna (Schratzberger et al., 2000; Leduc and Pilditch, 2013). Zeppilli et al. (2016) identified a positive exponential relationship between nematode biodiversity and ecosystem functioning and efficiency in different deep-sea habitats. Hence, reductions in

\section{REFERENCES}

Adiansyah, J. S., Rosano, M., Vink, S., and Keir, G. (2015). A framework for a sustainable approach to mine tailings management: disposal strategies. J. Clean. Prod. 108, 1050-1062. doi: 10.1016/j.jclepro.2015.07.139

Alongi, D. M., and Tenore, K. R. (1985). Effect of detritus supply on trophic relationships within experimental benthic food webs. I. Meiofauna-polychaete biodiversity and changes in community composition may result in decreased ecosystem functioning and a reduced resilience of the system to different additional stressors (Gessner and Hines, 2012; Steudel et al., 2012; Zeppilli et al., 2016).

We need to be aware of the differential response to burial with different substrates when assessing impacts of mine tailings placement on the benthic environment. This study shows that the particular characteristics of the sediment e.g., organic matter content, porosity or grain size strongly influence the biochemistry inside the sediments and the way the ecosystem responses to substrate burial. Therefore, more research is needed using substrate with similar characteristics of the effectively placed tailings. Furthermore, our study indicates that vast areas impacted by low tailings deposition might experience a reduced carbon mineralization capacity, especially over the short-term. While the thickness of mine tailings in the direct surrounding of the deposition site can reach very high values with deposition rates of several $\mathrm{m} \mathrm{y}^{-1}$, the seafloor may still be impacted by deposition rates of $1 \mathrm{~mm} \mathrm{y}^{-1}$ several $\mathrm{km}$ off the deposition site (Olsgard and Hasle, 1993). The wider implications will depend on the scale of tailings discharge and the resilience of the targeted ecosystem. If DSTP is implemented in more regions worldwide environmental managers need to be aware that even small deposition rates might negatively impact very large areas disrupting the functioning of important benthic environments.

\section{AUTHOR CONTRIBUTIONS}

$\mathrm{AKS}, \mathrm{DvO}$, and $\mathrm{AV}$ generated the project funding and conceived the idea of this integrated experiment, that was further developed and implemented by LM, LMe, TS, and SW. KG and SW provided further input to the conceptual design and practical implementation of the study. LM, SW, LMe, and TS collected and analyzed the data. The authors collectively interpreted the data. LMe and TS wrote the manuscript with input from all authors.

\section{ACKNOWLEDGMENTS}

This research was funded by the MIDAS project (grant agreement $\mathrm{n}^{\circ}$ 603418) under the European Union Seventh Framework Programme (FP7/2007-2013) awarded to AV, DvO, and AKS. The authors want to acknowledge A. Rigaux for her valuable assistance during the experiment and L. Pedersen and M. Berry for assistance at sea. We thank P. van Rijswijk, P. van Breugel, and J. Peene for technical assistance during sample analysis and $\mathrm{L}$. Burdorf for her assistance during $\mathrm{O}_{2}$ microprofile interpretations and subsequent $\mathrm{O}_{2}$ flux calculations. 
Bian, Z., Miao, X., Lei, S., Chen, S., Wang, W., and Struthers, S. (2012). The Challenges of reusing mining and mineral-processing wastes. Science 337, 702-703. doi: $10.1126 /$ science. 1224757

Bligh, E. G., and Dyer, W. J. (1959). A rapid method of total lipid extraction and purification. Can. J. Biochem. Physiol. 37, 911-917. doi: 10.1139/ 059-099

Bolam, S. G. (2011). Burial survival of benthic macrofauna following deposition of simulated dredged material. Environ. Monit. Assess. 181, 13-27. doi: 10.1007/s10661-010-1809-5

Bonvicini pagliai, A. M., Cognetti Varriale, A. M., Crema, R., Curini Galletti, M., and Vandini Zunarelli, R. (1985). Environmental impact of extensive dredging in a coastal marine area. Mar. Pollut. Bull. 16, 483-488. doi: 10.1016/0025-326X(85)90381-9

Boschker, H. T. S. (2004). "Linking microbial community structure and functioning: stable isotope $\left({ }^{13} \mathrm{C}\right)$ labeling in combination with PLFA analysis," in Molecular Microbial Ecology Manual, 2nd Edn., eds G. A. Kowalchuk, F. J. de Bruijn, I. M. Head, A. D. Akkermans, and J. D. van Elsas (Dordrecht: Kluwer Acad. Publishers), 1673-1688.

Boschker, H. T. S., and Middelburg, J. J. (2002). Stable isotopes and biomarkers in microbial ecology. FEMS Microbiol. Ecol. 40, 85-95. doi: 10.1111/j.1574-6941.2002.tb00940.x

Braeckman, U., Provoost, P., Gribsholt, B., Gansbeke, D. V., Middelburg, J. J., Soetaert, K., et al. (2010). Role of macrofauna functional traits and density in biogeochemical fluxes and bioturbation. Mar. Ecol. Prog. Ser. 399, 173-186. doi: 10.3354/meps08336

Bratton, J. F., Colman, S. M., and Seal, R. R. II. (2003). Eutrophication and carbon sources in Chesapeake Bay over the last 2700 yr: human impacts in context. Geochim. Cosmochim. Acta 67, 3385-3402. doi: 10.1016/S0016-7037(03)00131-5

Burd, B. J. (2002). Evaluation of mine tailings effects on a benthic marine infaunal community over 29 years. Mar. Environ. Res. 53, 481-519. doi: 10.1016/S0141-1136(02)00092-2

Chou, L. M., Yu, J. Y., and Loh, T. L. (2004). Impacts of sedimentation on soft-bottom benthic communities in the southern islands of Singapore. Hydrobiologia 515, 91-106. doi: 10.1023/B:HYDR.0000027321.23230.2f

Clarke, K. R., and Gorley, R. N. (2006). User Manual/Tutorial. Plymouth: Primer-E Ltd Plymouth.

Coull, B. C. (1999). Role of meiofauna in estuarine soft-bottom habitats. Aust. J. Ecol. 24, 327-343. doi: 10.1046/j.1442-9993.1999.00979.x

Cummings, V., Vopel, K., and Thrush, S. (2009). Terrigenous deposits in coastal marine habitats: influences on sediment geochemistry and behaviour of postsettlement bivalves. Mar. Ecol. Prog. Ser. 383, 173-185. doi: 10.3354/meps07983

Danovaro, R. (1996). Detritus-bacteria-Meiofauna interactions in a seagrass bed (Posidonia oceanica) of the NW Mediterranean. Mar. Biol. 127, 1-13. doi: 10.1007/BF00993638

Danovaro, R., Gambi, C., Dell'Anno, A., Corinaldesi, C., Fraschetti, S., Vanreusel, A., et al. (2008). Exponential decline of deep-sea ecosystem functioning linked to benthic biodiversity loss. Curr. Biol. 18, 1-8. doi: 10.1016/j.cub.2007.11.056.

Danovaro, R., Snelgrove, P. V. R., and Tyler, P. (2014). Challenging the paradigms of deep-sea ecology. Trends Ecol. Evol. 29, 465-475. doi: 10.1016/j.tree.2014.06.002

De Grave, S., and Whitaker, A. (1999). Benthic community re-adjustment following dredging of a muddy-maerl matrix. Mar. Pollut. Bull. 38, 102-108. doi: 10.1016/S0025-326X(98)00103-9

de Leo, F. C., Smith, C. R., Rowden, A. A., Bowden, D. A., and Clark, M. R. (2010). Submarine canyons: hotspots of benthic biomass and productivity in the deep sea. Proc. R. Soc. Lond. B Biol. Sci. 277, 2783-2792. doi: 10.1098/rspb.2010.0462

Deming, J. W., and Baross, J. A. (1993). "The early diagenesis of organic matter: bacterial activity," in Organic Geochemistry, Topics in Geobiology, eds M. H. Engel, S. A. Macko (New York, NY: Springer), 119-144.

Dernie, K. M., Kaiser, M. J., and Warwick, R. M. (2003). Recovery rates of benthic communities following physical disturbance. J. Anim. Ecol. 72, 1043-1056. doi: 10.1046/j.1365-2656.2003.00775.x

Diaz, R. J., and Rosenberg, R. (1995). Marine benthic hypoxia: a review of its ecological effects and the behavioural responses of benthic macrofauna. Oceanogr. Mar. Biol. Annu. Rev. 33, 245-243.

Eiler, A., Langenheder, S., Bertilsson, S., and Tranvik, L. J. (2003). Heterotrophic bacterial growth efficiency and community structure at different natural organic carbon concentrations. Appl. Environ. Microbiol. 69, 3701-3709. doi: 10.1128/AEM.69.7.3701-3709.2003

Evrard, V., Soetaert, K., Heip, C. H. R., Huettel, M., Xenopoulos, M. A., and Middelburg, J. J. (2010). Feature article carbon and nitrogen flows through the benthic food web of a photic subtidal sandy sediment. Mar. Ecol. Prog. Ser. 416, 1-16. doi: 10.3354/meps08770

Fennel, K. (2010). The role of continental shelves in nitrogen and carbon cycling: Northwestern North Atlantic case study. Ocean Sci. 6:539. doi: 10.5194/os-6-539-2010

Franks, D. M., Boger, D. V., Côte, C. M., and Mulligan, D. R. (2011). Sustainable development principles for the disposal of mining and mineral processing wastes. Resour. Policy 36, 114-122. doi: 10.1016/j.resourpol.2010.12.001

Gerlach, S. A. (1971). On the importance of marine meiofauna for benthos communities. Oecologia 6, 176-190. doi: 10.1007/BF00345719

Gerlach, S. A. (1978). Food-chain relationships in subtidal silty sand marine sediments and the role of meiofauna in stimulating bacterial productivity. Oecologia 33, 55-69. doi: 10.1007/BF00376996

Gessner, M. O., and Hines, J. (2012). Stress as a modifier of biodiversity effects on ecosystem processes? J. Anim. Ecol. 81, 1143-1145. doi: 10.1111/1365-2656.12011

Gilbertson, W. W., Solan, M., and Prosser, J. I. (2012). Differential effects of microorganism-invertebrate interactions on benthic nitrogen cycling. FEMS Microbiol. Ecol. 82, 11-22. doi: 10.1111/j.1574-6941.2012.01400.x

Glud, R. N. (2008). Oxygen dynamics of marine sediments. Mar. Biol. Res. 4, 243-289. doi: 10.1080/17451000801888726

Guilini, K., Soltwedel, T., van Oevelen, D., and Vanreusel, A. (2011). Deep-sea nematodes actively colonise sediments, irrespective of the presence of a pulse of organic matter: results from an in-situ experiment. PLOS ONE 6:e18912. doi: 10.1371/journal.pone.0018912

Hale, R., Calosi, P., McNeill, L., Mieszkowska, N., and Widdicombe, S. (2011). Predicted levels of future ocean acidification and temperature rise could alter community structure and biodiversity in marine benthic communities. Oikos 120, 661-674. doi: 10.1111/j.1600-0706.2010.19469.x

Heip, C. H. R., Vincx, M., and Vranken, G. (1995). The ecology of marine nematodes. Oceanogr. Mar. Biol. Ann. Rev. 23, 399-489.

Hendelberg, M., and Jensen, P. (1993). Vertical distribution of the nematode fauna in a coastal sediment influenced by seasonal hypoxia in the bottom water. Ophelia 37, 83-94. doi: 10.1080/00785326.1993.10429909

Higgins, R. P., and Thiel, H. (1988). Introduction to the Study of Meiofauna. Washington, DC: Smithson. Inst. Press

Hinchey, E. K., Schaffner, L. C., Hoar, C. C., Vogt, B. W., and Batte, L. P. (2006). Responses of estuarine benthic invertebrates to sediment burial: the importance of mobility and adaptation. Hydrobiologia 556, 85-98. doi: 10.1007/s10750-005-1029-0

Hofmann, E. E., Cahill, B., Fennel, K., Friedrichs, M. A. M., Hyde, K., Lee, C., et al. (2011). Modeling the dynamics of continental shelf carbon. Annu. Rev. Mar. Sci. 3, 93-122. doi: 10.1146/annurev-marine-120709-142740

Ishida, H., Golmen, L. G., West, J., Krueger, M., Coombs, P., Berge, J. A., et al. (2013). Effects of $\mathrm{CO}_{2}$ on benthic biota: an in situ benthic chamber experiment in Storfjorden (Norway). Mar. Pollut. Bull. 73, 443-451. doi: 10.1016/j.marpolbul.2013.02.009

Jamieson, H. E. (2011). Geochemistry and mineralogy of solid mine waste: essential knowledge for predicting environmental impact. Elements 7, 381-386. doi: $10.2113 /$ gselements.7.6.381

Jansson, B.-O. (1967). The significance of grain size and pore water content for the interstitial fauna of sandy beaches. Oikos 18, 311-322. doi: 10.2307/3565107

Jones, H., and Boger, D. V. (2012). Sustainability and waste management in the resource industries. Ind. Eng. Chem. Res. 51, 10057-10065. doi: $10.1021 /$ ie202963z

Josefson, A. B., and Widbom, B. (1988). Differential response of benthic macrofauna and meiofauna to hypoxia in the Gullmar Fjord basin. Mar. Biol. 100, 31-40. doi: 10.1007/BF00392952

Kirchman, D. L., and Rich, J. H. (1997). Regulation of bacterial growth rates by dissolved organic carbon and temperature in the equatorial Pacific ocean. Microb. Ecol. 33, 11-20. doi: 10.1007/s00248 9900003

Kvassnes, A. J. S., and Iversen, E. (2013). Waste sites from mines in Norwegian Fjords. Mineralproduksjon 3, A27-A38. 
Leduc, D., and Pilditch, C. A. (2013). Effect of a physical disturbance event on deep-sea nematode community structure and ecosystem function. J. Exp. Mar. Biol. Ecol. 440, 35-41. doi: 10.1016/j.jembe.2012.11.015

Levin, L. A., Mengerink, K., Gjerde, K. M., Rowden, A. A., Van Dover, C. L., Clark, M. R., et al. (2016). Defining serious harm to the marine environment in the context of deep-seabed mining. Mar. Policy 74, 245-259. doi: 10.1016/j.marpol.2016.09.032

Lohrer, A. M., Thrush, S. F., and Gibbs, M. M. (2004). Bioturbators enhance ecosystem function through complex biogeochemical interactions. Nature 431, 1092-1095. doi: 10.1038/nature03042

Louis, K., and Siegel, A. (2011). "Cell viability analysis using trypan blue: manual and automated methods," in Mammalian Cell Viability, Methods in Molecular Biology, ed M. J. Stoddart (New York, NY: Humana Press), 7-12.

Maurer, D., Keck, R. T., Tinsman, J. C., Leathem, W. A., Wethe, C., Lord, C., et al. (1986). Vertical migration and mortality of marine benthos in dredged material: a synthesis. Int. Rev. Gesamten Hydrobiol. Hydrogr. 71, 49-63. doi: 10.1002/iroh.19860710106

Mengerink, K. J., Dover, C. L. V., Ardron, J., Baker, M., Escobar-Briones, E., Gjerde, K., et al. (2014). A call for deep-ocean stewardship. Science 344, 696-698. doi: $10.1126 /$ science. 1251458

Mermillod-Blondin, F., Rosenberg, R., Francois-Carcaillet, F., Norling, K., and Mauclaire, L. (2004). Influence of bioturbation by three benthic infaunal species on microbial communities and biogeochemical processes in marine sediment. Aquat. Microb. Ecol. 36, 271-284. doi: 10.3354/ame 036271

Meysman, F. J. R., Middelburg, J. J., and Heip, C. H. R. (2006). Bioturbation: a fresh look at Darwin's last idea. Trends Ecol. Evol. 21, 688-695. doi: 10.1016/j.tree.2006.08.002

Middelburg, J. J., Barranguet, C., Boschker, H. T. S., Herman, P. M. J., Moens, T., and Heip, C. H. R. (2000). The fate of intertidal microphytobenthos carbon: An in situ 13C-labeling study. Limnol. Oceanogr. 45, 1224-1234. doi: 10.4319/lo.2000.45.6.1224

Middelburg, J. J., Duarte, C. M., and Gattuso, J.-P. (2005). "Respiration in coastal benthic communities,"in Respiration in Aquatic Ecosystems, eds P. A. del Giorgio and P. J. le B. Williams (Oxford: Oxford University Press), 206-244.

Miller, D. C., Muir, C. L., and Hauser, O. A. (2002). Detrimental effects of sedimentation on marine benthos: what can be learned from natural processes and rates? Ecol. Eng. 19, 211-232. doi: 10.1016/s0925-8574(02)00081-2

Moens, T., and Vincx, M. (1997). Observations on the feeding ecology of estuarine nematodes. J. Mar. Biol. Assoc. U. K. 77, 211-227. doi: $10.1017 /$ S0025315400033889

Moodley, L., Boschker, H. T. S., Middelburg, J. J., Pel, R., Herman, P. M. J., Deckere, E., et al. (2000a). Ecological significance of benthic foraminifera: 13C labelling experiments. Mar. Ecol. Prog. Ser. 202, 289-295. doi: 10.3354/meps202289

Moodley, L., Chen, G., Heip, C., and Vincx, M. (2000b). Vertical distribution of meiofauna in sediments from contrasting sites in the adriatic sea: clues to the role of abiotic versus biotic control. Ophelia 53, 203-212. doi: 10.1080/00785326.2000.10409450

Moodley, L., Heip, C. H. R., and Middelburg, J. J. (1998). Benthic activity in sediments of the northwestern Adriatic Sea: sediment oxygen consumption, macro- and meiofauna dynamics. J. Sea Res. 40, 263-280. doi: 10.1016/S1385-1101(98)00026-4

Moodley, L., Middelburg, J. J., Boschker, H. T. S., Duineveld, G. C. A., Pel, R., Herman, P. M. J., et al. (2002). Bacteria and Foraminifera: key players in a short term deep-sea benthic response to phytodetritus. Mar. Ecol. Prog. Ser. 236, 23-29. doi: 10.3354/meps236023

Moodley, L., Middelburg, J. J., Soetaert, K., Boschker, H. T. S., Herman, P. M. J., and Heip, C. H. R. (2005). Similar rapid response to phytodetritus deposition in shallow and deep-sea sediments. J. Mar. Res. 63, 457-469. doi: $10.1357 / 0022240053693662$

Moodley, L., van der Zwaan, G. J., Herman, P. M. J., Kempers, L., and Breugel, P. (1997). Differential response of benthic meiofauna to anoxia with special reference to Foraminifera (Protista: Sarcodina). Mar. Ecol. Prog. Ser. 158, 151-163. doi: 10.3354/meps158151

Muller-Karger, F. E., Varela, R., Thunell, R., Luerssen, R., Hu, C., and Walsh, J. J. (2005). The importance of continental margins in the global carbon cycle. Geophys. Res. Lett. 32:L01602. doi: 10.1029/2004GL021346
Olsgard, F., and Hasle, J. R. (1993). Impact of waste from titanium mining on benthic fauna. J. Exp. Mar. Biol. Ecol. 172, 185-213. doi: 10.1016/0022-0981(93)90097-8

Ott, J. A. (1972). Determination of fauna boundaries of nematodes in an intertidal sand flat. Int. Rev. Gesamten Hydrobiol. Hydrogr. 57, 645-663. doi: 10.1002/iroh.19720570413

Ott, J., and Schiemer, F. (1973). Respiration and anaerobiosis of free living nematodes from marine and limnic sediments. Neth. J. Sea Res. 7, 233-243. doi: 10.1016/0077-7579(73)90047-1

Piot, A., Nozais, C., and Archambault, P. (2013). Meiofauna affect the macrobenthic biodiversity-ecosystem functioning relationship. Oikos 123, 203-213. doi: 10.1111/j.1600-0706.2013.00631.x,

Ramirez-Llodra, E., Trannum, H. C., Evenset, A., Levin, L. A., Andersson, M., Finne, T. E., et al. (2015). Submarine and deep-sea mine tailing placements: A review of current practices, environmental issues, natural analogs and knowledge gaps in Norway and internationally. Mar. Pollut. Bull. 97, 13-35. doi: 10.1016/j.marpolbul.2015.05.062

R.Core Team (2013). R: A Language and Environment for Statistical Computing. Vienna: R Foundation for Statistical Computing.

Renaud, P. E., Morata, N., Ambrose, W. G. Jr., Bowie, J. J., and Chiuchiolo, A. (2007). Carbon cycling by seafloor communities on the eastern Beaufort Sea shelf. J. Exp. Mar. Biol. Ecol. 349, 248-260. doi: 10.1016/j.jembe.2007.05.021

Rowe, G. T., and Deming, J. W. (1985). The role of bacteria in the turnover of organic carbon in deep-sea sediments. J. Mar. Res. 43, 925-950. doi: $10.1357 / 002224085788453877$

Schade, H., Mevenkamp, L., Guilini, K., Meyer, S., Gorb, S. N., Abele, D., et al. (2016). Simulated leakage of high $\mathrm{pCO}_{2}$ water negatively impacts bivalve dominated infaunal communities from the Western Baltic Sea. Sci. Rep. 6:31447. doi: 10.1038/srep31447

Schratzberger, M., Rees, H. L., and Boyd, S. E. (2000). Effects of simulated deposition of dredged material on structure of nematode assemblages - the role of burial. Mar. Biol. 136, 519-530. doi: 10.1007/s002270050712

Schratzberger, M., and Warwick, R. M. (1998). Effects of physical disturbance on nematode communities in sand and mud: a microcosm experiment. Mar. Biol. 130, 643-650. doi: 10.1007/s002270050286

Seiderer, L. J., and Newell, R. C. (1999). Analysis of the relationship between sediment composition and benthic community structure in coastal deposits: Implications for marine aggregate dredging. ICES J. Mar. Sci. 56, 757-765. doi: 10.1006/jmsc.1999.0495

Smit, M. G. D., Holthaus, K. I. E., Trannum, H. C., Neff, J. M., Kjeilen-Eilertsen, G., Jak, R. G., et al. (2008). Species sensitivity distributions for suspended clays, sediment burial, and grain size change in the marine environment. Environ. Toxicol. Chem. 27, 1006-1012. doi: 10.1897/07-339.1

Snelgrove, P. V. R., and Butman, C. A. (1994). Animal-sediment relationships revisited: cause versus effect. Oceanogr. Mar. Biol. Annu. Rev. 32, 111-177.

Steudel, B., Hector, A., Friedl, T., Löfke, C., Lorenz, M., Wesche, M., et al. (2012). Biodiversity effects on ecosystem functioning change along environmental stress gradients. Ecol. Lett. 15, 1397-1405. doi: 10.1111/j.1461-0248.2012.01863.x

Steyaert, M., Moodley, L., Nadong, T., Moens, T., Soetaert, K., and Vincx, M. (2007). Responses of intertidal nematodes to short-term anoxic events. J. Exp. Mar. Biol. Ecol. 345, 175-184. doi: 10.1016/j.jembe.2007.03.001

Sweetman, A. K., Chelsky, A., Pitt, K. A., Andrade, H., van Oevelen, D., and Renaud, P. E. (2016). Jellyfish decomposition at the seafloor rapidly alters biogeochemical cycling and carbon flow through benthic food-webs. Limnol. Oceanogr. 61, 1449-1461. doi: 10.1002/lno.10310

Sweetman, A. K., Middelburg, J. J., Berle, A. M., Bernardino, A. F., Schander, C., Demopoulos, A. W. J., et al. (2010). Impacts of exotic mangrove forests and mangrove deforestation on carbon remineralization and ecosystem functioning in marine sediments. Biogeosciences 7, 2129-2145. doi: 10.5194/bg-7-2129-2010

Sweetman, A. K., Norling, K., Gunderstad, C., Haugland, B. T., and Dale, T. (2014). Benthic ecosystem functioning beneath fish farms in different hydrodynamic environments. Limnol. Oceanogr. 59, 1139-1151. doi: 10.4319/lo.2014.59.4.1139

Thrush, S. F., and Dayton, P. K. (2002). Disturbance to marine benthic habitats by trawling and dredging: implications for marine biodiversity. Annu. Rev. Ecol. Syst. 33, 449-473. doi: 10.1146/annurev.ecolsys.33.010802.150515 
Thurber, A. R., Sweetman, A. K., Narayanaswamy, B. E., Jones, D. O. B., Ingels, J., and Hansman, R. L. (2014). Ecosystem function and services provided by the deep sea. Biogeosciences 11, 3941-3963. doi: 10.5194/bg-113941-2014

Vanaverbeke, J., Franco, M., van Oevelen, D., Moodley, L., Provoost, P., Steyaert, M., et al. (2008). "Benthic responses to sedimentation of phytoplankton on the Belgian Continental Shelf," in Current Status of Eutrophication in the Belgian Coastal Zone, eds V. Coursseau, C. Lancelot, and D. Cox (Brussels: Presses Universitaires de Bruxelles), 73-90.

Van Colen, C., Montserrat, F., Verbist, K., Vincx, M., Steyaert, M., Vanaverbeke, J., et al. (2009). Tidal flat nematode responses to hypoxia and subsequent macrofauna-mediated alterations of sediment properties. Mar. Ecol. Prog. Ser. 381, 189-197. doi: 10.3354/meps07914

van Oevelen, D., Middelburg, J. J., Soetaert, K., and Moodley, L. (2006a). The fate of bacterial carbon in an intertidal sediment: modeling an in situ isotope tracer experiment. Limnol. Oceanogr. 51, 1302-1314. doi: 10.4319/lo.2006. 51.3.1302

van Oevelen, D., Soetaert, K., Middelburg, J. J., Herman, P. M. J., Moodley, L., Hamels, I., et al. (2006b). Carbon flows through a benthic food web: Integrating biomass, isotope and tracer data. J. Mar. Res. 64, 453-482. doi: $10.1357 / 002224006778189581$

Vogt, C. (2013). International Assessment of Marine and Riverine Disposal of Mine Tailings. Final Report Adopted by the International Maritime Organization (London Convention/Protocol). IMO.

Walsh, J. J. (1991). Importance of continental margins in the marine biogeochemical cycling of carbon and nitrogen. Nature 350, 53-55. doi: $10.1038 / 350053 \mathrm{a} 0$

Wei, C.-L., Rowe, G. T., Escobar-Briones, E., Boetius, A., Soltwedel, T., Caley, M. J., et al. (2010). Global patterns and predictions of seafloor biomass using random forests. PLOS ONE 5:e15323. doi: 10.1371/journal.pone.0015323

Weigelt, M., and Rumohr, H. (1986). Effects of wide-range oxygen depletion on benthic fauna and demersal fish in Keil Bay 1981-1983. Meeresforschung 31, 124-136.

Wentworth, C. K. (1922). A scale of grade and class terms for clastic sediments. J. Geol. 30, 377-392. doi: 10.1086/622910
Wernberg, T., Smale, D. A., and Thomsen, M. S. (2012). A decade of climate change experiments on marine organisms: procedures, patterns and problems. Glob. Change Biol. 18, 1491-1498. doi: 10.1111/j.1365-2486.2012.02656.x

Wetzel, M. A., Fleeger, J. W., and Powers, S. P. (2001). "Effects of hypoxia and anoxia on meiofauna: a review with new data from the Gulf of Mexico," in Coastal Hypoxia: Consequences for Living Resources and Ecosystems, eds N. N. Rabalais and R. E. Turner (Washington, DC: American Geophysical Union), 165-184. doi: 10.1029/CE058p0165

Widdicombe, S., Dashfield, S. L., McNeill, C. L., Needham, H. R., Beesley, A., McEvoy, A., et al. (2009). Effects of $\mathrm{CO}_{2}$ induced seawater acidification on infaunal diversity and sediment nutrient fluxes. Mar. Ecol. Prog. Ser. 379, 59-75. doi: $10.3354 /$ meps 07894

Wieser, W., Ott, J., Schiemer, F., and Gnaiger, E. (1974). An ecophysiological study of some meiofauna species inhabiting a sandy beach at Bermuda. Mar. Biol. 26, 235-248. doi: $10.1007 / \mathrm{BF} 00389254$

Womersley, C., and Ching, C. (1989). Natural dehydration regimes as a prerequisite for the successful induction of anhydrobiosis in the nematode Rotylenchulus reniformis. J. Exp. Biol. 143, 359-372.

Young, C. M. (2003). Reproduction, Development and Life-History Traits. Ecosyst. Deep Ocean, Ecosystems of the world.

Zeppilli, D., Pusceddu, A., Trincardi, F., and Danovaro, R. (2016). Seafloor heterogeneity influences the biodiversity-ecosystem functioning relationships in the deep sea. Sci. Rep. 6:26352. doi: 10.1038/srep26352

Conflict of Interest Statement: The authors declare that the research was conducted in the absence of any commercial or financial relationships that could be construed as a potential conflict of interest.

Copyright (c) 2017 Mevenkamp, Stratmann, Guilini, Moodley, van Oevelen, Vanreusel, Westerlund and Sweetman. This is an open-access article distributed under the terms of the Creative Commons Attribution License (CC BY). The use, distribution or reproduction in other forums is permitted, provided the original author(s) or licensor are credited and that the original publication in this journal is cited, in accordance with accepted academic practice. No use, distribution or reproduction is permitted which does not comply with these terms. 